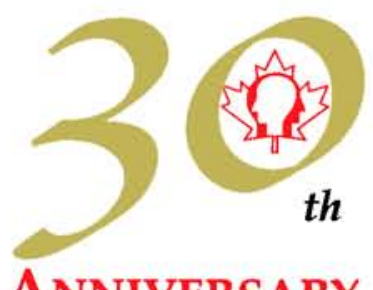

\title{
THE CANADIAN JOURNAL OF
}

Neurological Sciences

LE JOURNAL CANADIEN DES

ANNIVERSARY

Sciences Neurologiques

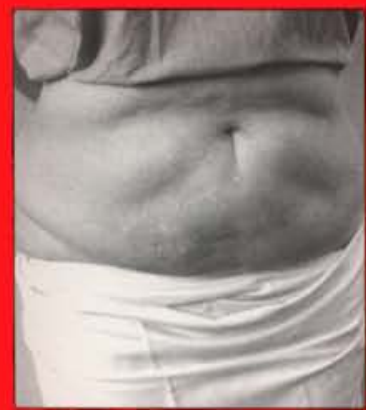

Lipoatrophy

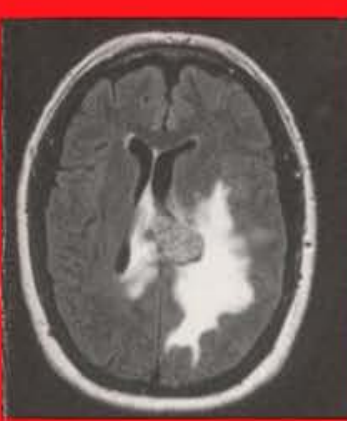

Renal Cell Carcinoms

39th CANADIAN CONGRESS OF

NEUROLOGICAL SCIENCES

June $8-12,2004$

Calgary, Alberta

\section{EDITORIALS}

1 Intellectual Investment in Your Journal: the Next 30 Years!

Douglas Zochodne

3 The Burden of Seizures in Children

Michael I. Shevell

5 Industry and Academic Medicine: A Dangerous Liaison?

John W. Norris

\section{REVIEW ARTICLES}

7 Progress in Clinical Neurosciences: Parkinson's Disease with Dementia and Dementia with Lewy Bodies CME Richard Camicioli and Nancy Fisher

22 Carotid Endarterectomy: A Review CME

J. Max Findlay, B. Elaine Marchak, David M. Pelz. Thomas E. Feasby

37 Multiple Sclerosis in its European Matrix: Some Aspects of History. Mechanisms and Treatment Ian McDonald

\section{ORIGINAL ARTICLES}

48 The Burden of Seizures in Manitoba Children: A Population-Based Study Anita L. Kozyrskyj, Asuri N. Prasad

53 The Endovascular Management of Superior Cerebellar Artery Aneurysms Charles Haw, Robert Willinsky, Ronit Agid, Karel TerBrugge

58 Lipoatrophy in Patients with Multiple Sclerosis on Glatiramer Acetate Catherine M. Edgar, Donald G. Brunet, Paul Fenton, E. Vee McBride, Peter Green

64 Do General and Multiple Sclerosis-Specific Quality of Life Instruments Differ? Fraser Moore, Christina Wolfson, Lubo Alexandrov, Yves Lapierre

72 Effectiveness of a Multidisciplinary Treatment Program for Chronic Daily Headache Jane E. Magnusson, Connie M. Riess, Werner J. Becker

80 Jugular Bulb Oximetry for Prediction of Vasospasm Following Subarachnoid Hemorrhage Navraj S. Heran, Stephen J. Hentschel, Brian Toyota

\section{EXPERIMENTAL NEUROSCIENCES}

87 Intraspinal Transplantation of hNT Neurons in the Lesioned Adult Rat Spinal Cord Sean Dennis Christie, Damaso Sadi and Ivar Mendez

\section{NEUROIMAGING HIGHLIGHT}

97 Submitted by: Lynn Lacasse, Cheemun Lum

CASE REPORTS (See Contents Page)

The official Journal of: The Canadian Neurological Society, The Canadian Neurosurgical Society, The Canadian Society of Clinical Neurophysiologists, The Canadian Association of Child Neurology 


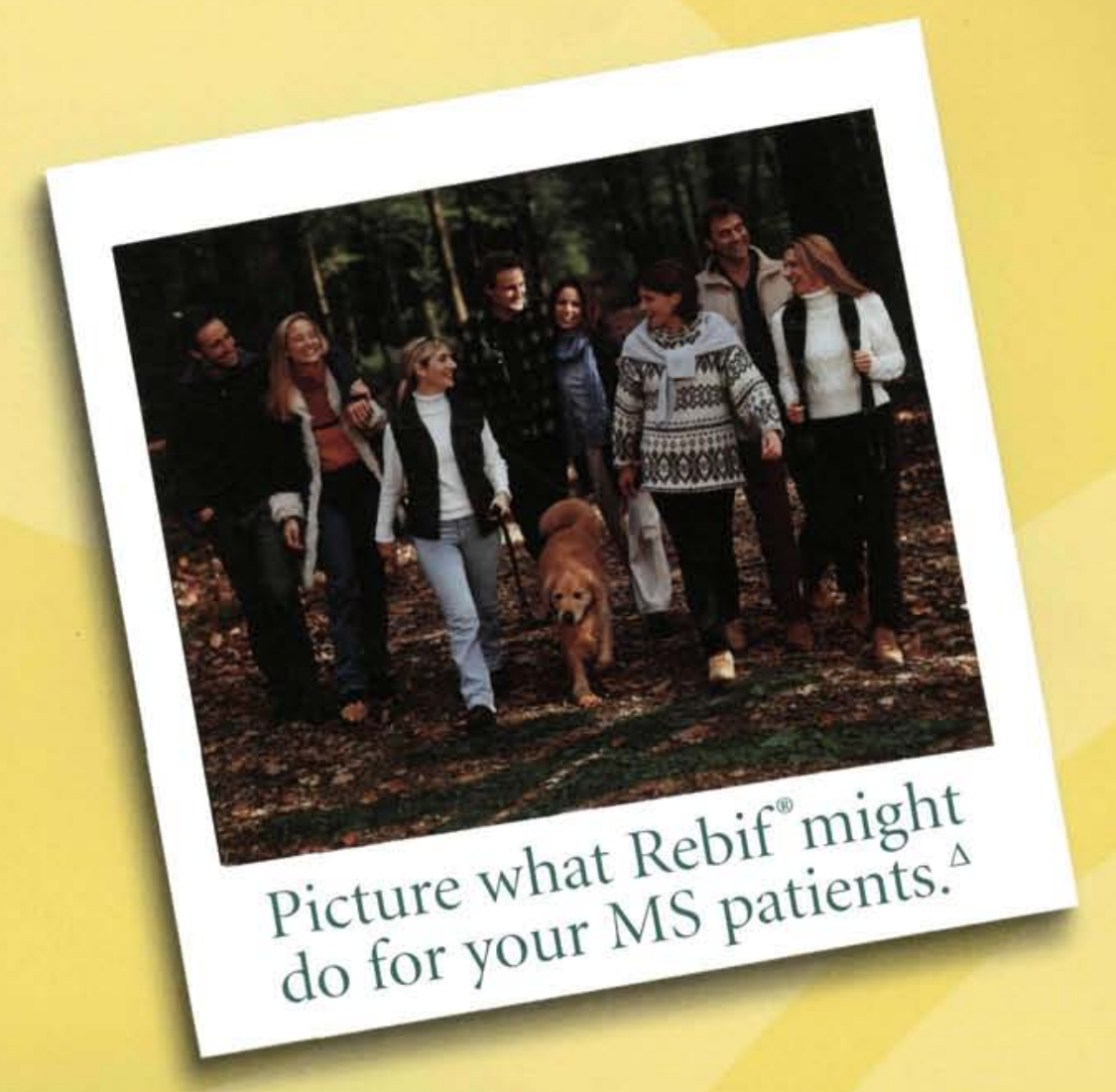

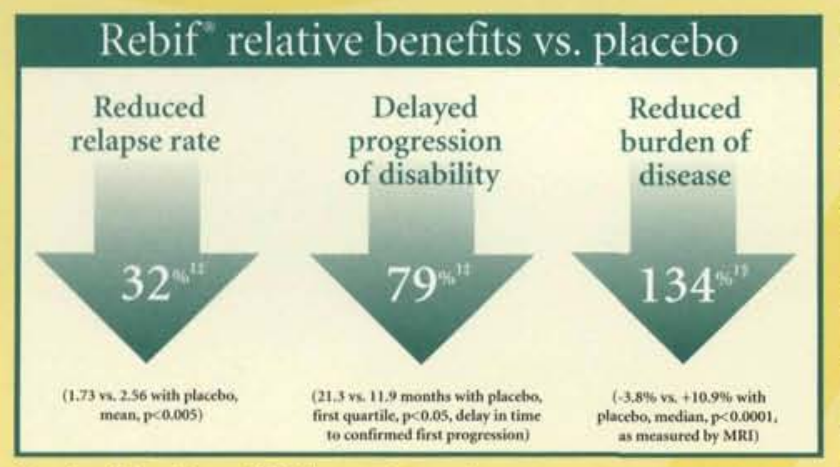

Results of the 44 mcg TIW dose at 2 years.
In two pivotal studies, including a total of 628 patients, Rebif showed significant efficacy in three major outcomes (relapses, disability progression and MRI). ${ }^{1,2}$

Its ability to affect the course of the disease ${ }^{2}$ has made Rebif not only a good first-line choice for relapsing-remitting $\mathrm{MS}$, but the leading drug in its class. $^{3}$

Rebif is generally well-tolerated. The most common adverse events are often manageable and decrease in frequency and severity over time. ${ }^{2+}$

Rebif alters the natural course of relapsing-remitting MS. ${ }^{2}$

Rebif* is indicated for the treatment of relapsing-remitting multiple sclerosis in patients with an EDSS between 0 and 5.0 , to reduce the number and severity of clinical exacerbations, slow the progression of physical disability, reduce the requirement for steroids, and reduce the number of hospitalizations for treatment of multiple sclerosis. The efficacy of Rebif has been confirmed by $\mathrm{T}_{1}-\mathrm{Gd}$ enhanced and $\mathrm{T}_{2}$ (burden of disease) MRI evaluations.

† The most common adverse events reported are injection-site disorders (all) ( $92.4 \%$ vs. $38.5 \%$ placebo), upper respiratory tract infections $(74.5 \%$ vs. $85.6 \%$ placebo), headache $(70.1 \%$ vs. $62.6 \%$ placebo), flu-like symptoms $(58.7 \%$ vs. $51.3 \%$ placebo), fatigue ( $41.3 \%$ vs. $35.8 \%$ placebo $)$ and fever $(27.7 \%$ vs. $15.5 \%$ placebo). Evidence of safety and efficacy derived from 2 -year data only. Please see product monograph for full prescribing information. ${ }^{2}$

\# Randomized, double-blind, placebo-controlled trial. Rebif $44 \mathrm{mcg}$ TIW group ( $\mathrm{n}=184$ ), Rebif $22 \mathrm{mcg}$ TIW group ( $\mathrm{n}=189$ ), placebo group $(\mathrm{n}=187)$.

$\Delta$ Fictitious case may not be representative of results for the general population. 


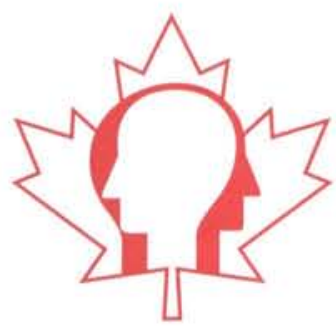

\section{THE CANADIAN JOURNAL OF}

\section{Neurological Sciences}

\section{LE JOURNAL CANADIEN DES}

\section{Sciences Neurologiques}

\section{EDITORIALS}

1 Intellectual Investment in Your Journal: the Next 30 Years!

Douglas Zochodne

3 The Burden of Seizures in Children

Michael I. Shevell

$5 \quad$ Industry and Academic Medicine: A Dangerous Liaison? John W. Norris

\section{REVIEW ARTICLES}

7 Progress in Clinical Neurosciences: Parkinson's Disease CME with Dementia and Dementia with Lewy Bodies

Richard Camicioli and Nancy Fisher

22 Carotid Endarterectomy: A Review

CME J.Max Findlay, B. Elaine Marchak, David M. Pelz, Thomas E. Feasby

37 Multiple Sclerosis in its European Matrix: Some Aspects of History, Mechanisms and Treatment

Ian McDonald

\section{ORIGINAL ARTICLES}

48 The Burden of Seizures in Manitoba Children: A Population-Based Study

Anita L. Kozyrskyj, Asuri N. Prasad

53 The Endovascular Management of Superior Cerebellar Artery Aneurysms

Charles Haw, Robert Willinsky, Ronit Agid, Karel TerBrugge

Lipoatrophy in Patients with Multiple Sclerosis on Glatiramer Acetate

Catherine M. Edgar, Donald G. Brunet, Paul Fenton, E. Vee McBride, Peter Green

64 Do General and Multiple Sclerosis-Specific Quality of Life Instruments Differ?

Fraser Moore, Christina Wolfson, Lubo Alexandrov, Yves Lapierre

Effectiveness of a Multidisciplinary Treatment Program for Chronic Daily Headache

Jane E. Magnusson, Connie M. Riess, Werner J. Becker
80 Jugular Bulb Oximetry for Prediction of Vasospasm Following Subarachnoid Hemorrhage

Navraj S. Heran, Stephen J. Hentschel, Brian Toyota

\section{EXPERIMENTAL NEUROSCIENCES}

87 Intraspinal Transplantation of hNT Neurons in the Lesioned Adult Rat Spinal Cord

Sean Dennis Christie, Damaso Sadi and Ivar Mendez

\section{NEUROIMAGING HIGHLIGHT}

97 Submitted by: Lynn Lacasse, Cheemun Lum

\section{CASE REPORTS}

99 Can rt-PA be Administered to the Wrong Patient? Two

Patients with Somatoform Disorder

Mikael S. Mouradian, Jennifer Rodgers, Jodi Kashmere, Glen Jickling, Jennifer McCombe, Derek J Emery,

Andrew M. Demchuk, Ashfaq Shuaib

102 Bony Metastases of Anaplastic Oligodendroglioma Respond to Temozolomide

Tara Morrison, Juan M. Bilbao, Guisheng Yang, James R. Perry

109 Lacunar Stroke Associated with Methylphenidate Abuse Hamid Sadeghian

112 Fabry's Disease Presenting as Stroke in a Young Female Paul S. Giacomini, Patrick T. Shannon, Joe T.R. Clarke, Cheryl Jaigobin

115 Renal Cell Carcinoma Metastatic to the Choroid Mimicking Intraventricular Meningioma

Alfredo Quinones-Hinojosa, Edward F. Chang, Saad A. Khan, Michael T. Lawton, Michael W. McDermott

121 Contralateral Motor Automatisms in Neocortical Temporal Lobe Epilepsy

Seyed M. Mirsattari, Donald H. Lee, Warren T. Blume

125 Books Received

125 Book Reviews

130 Calendar of Events

A-8 Information for Authors

A-13 Preliminary Program -

39th Canadian Congress of

Neurological Sciences - Calgary, AB
CMIE Visit www.cens.org for instructions on taining online Journal CME credits 


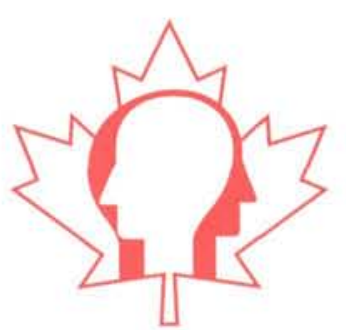

Neurological Sciences

LE JOURNAL CANADIEN DES

Sciences Neurologiques

Editor-in-Chief/Rédacteur en chef

Douglas W. Zochodne CALGARY, AB

Associate Editors/Rédacteurs associés

William A. Fletcher CALGARY, AB

Andres M. Lozano TORONTO, ON

Past Editors/Anciens rédacteurs en chef

James A. Sharpe TORONTO, ON

Robert G. Lee CALGARY, AB

Robert T. Ross WINNIPEG, MB

(Emeritus Editor, Founding Editor)

Editorial Board/Conseil Scientifique

Timothy J. Benstead HALIFAX, NS

J. Gregory Cairncross CALGARY, AB

Richard Desbiens QUEBEC CITY, QC

J. Max Findlay EDMONTON, AB

Ian Fleetwood HALIFAX, NS

Hans-Peter Hartung DUSSELDORF, GERMANY

Alan C. Jackson KINGSTON, ON

Jack Jhamandas EDMONTON, AB

Daniel Keene OTTAWA, ON

Douglas Kondziolka PITTSBURGH, PA, USA

Terence Myles CALGARY, AB

David Ramsay LONDON, ON

Peter M. Richardson LONDON, UK

Guy Rouleau MONTREAL, QC

Michael Shevell MONTREAL, QC

Paul Steinbok VANCOUVER, BC

Oksana Suchowersky CALGARY, AB

Samuel Wiebe LONDON, ON

G. Bryan Young LONDON, ON

\section{SECTION EDITORS/CONSEIL DE RÉDACTION}

Neuroimaging Highlight/Neuroimagerie

Mark Hudon CALGARY, AB

Richard Farb TORONTO, ON

Neuropathological Conference/Conférence sur la neuropathologie

David Ramsay LONDON, ON

Book Review/Critiques de livres

Christopher White CALGARY, AB

Electronic Editor/Rédacteur d'électronique

Daniel Keene OTTAWA, ON

Managing Director/Gérant directrice

Sally A. Gregg CALGARY, AB

\section{Publications Committee/Comité de Rédaction}

Joseph Chu ETOBICOKE, ON

Noel Lowry SASKATOON, SK

Richard McLachlan LONDON, ON

Owen Williams WINNIPG, MB
The official journal of: / La Revue officielle de:

The Canadian Neurological Society

La Société Canadienne de Neurologie

The Canadian Neurosurgical Society

La Société Canadienne de Neurochirurgie

The Canadian Society of Clinical Neurophysiologists

La Société Canadienne de Neurophysiologie Clinique

The Canadian Association of Child Neurology

L'Association Canadienne de Neurologie Pédiatrique

The permanent secretariat for the four societies and the Canadian Congress of Neurological Sciences is at:

Le secrétariat des quatre associations et du Congrès Canadien des Sciences Neurologiques est situe en permanence à:

7015 Macleod Trail SW. Suite 709. Calgary AB, Canada T2H 2K6.

The Canadian Joumal of Neurological Sciences is published quarterly. The annual subscription rate for Individuals are: C\$80 (Canada), US580 (USA), and US\$85 (elsewhere). Subscription rates for Institutions are: CS90 (Canada). US\$90 (USA). and US\$95 (elsewhere), Resident, intern and student rates are available. See www.cjns.org for details. Single copies C\$22 each plus postage and handling. All manuscripts and communications should be sent to: Canadian Joumal of Neurological Sciences, PO Box 5456, Station A, Calgary, AB Canada T2H I X8. Courier to: 709 7015 Macleod Trail SW, Calgary, AB Canada T2H 2K6. Telephone (403) 229-9575; Fax (403) 229-1661. E-mail: journal@ cjns org: Website: www.cjns.org COPYRIGHTO 2004 by THE CANADIAN JOURNAL OF NEUROLOGICAL SCI ENCES INC. All rights reserved. No part of this joumal may be reproduced in any form without the prior permission of The Canadian Journal of Neurological Sciences. Mailed under Publications Mail Agreement no: 40007777; Registration no: 09824. Postage paid at Calgary, Alberta. This journal is indexed by Aquatic Sciences and Fisheries Abstracts, ASCA - Automatic Subject Citation Alert, Biological Abstracts, Chemical Abstracts, Current Advances in Ecological Sciences, Current Contents (Clinical Medicine and Life Sciences), Dent. Index, e-psyche, Exerpta Medica, Inder Medicus, Industrial Science Review, INIS Atomindex, Inpharma, Journal Watch Neurology. International Abstracts in Biological Sciences, Laboratory Hasards Bulletin. Neurosciences Citation Index. Nutrition Abstracts. Nutrition Research Newsletter, Pharmaeconomics and Outcome News, Reactions Weekly. Referativni Zhumal, Science Citation Index. Weed Abstracts

Le Journal Canadien des Sciences Neurologiques est publié trimestriellement. Labonnement annuel est de 80 \$C (non-membres au Canada): 80 SÉ-U (Etats Unis) et 85 SÉ-U (ailleurs); l'abonnement annuel for pour les institutions est de 90 SC (non-membres au Canada); 90 SÉ-U (Etats Unis) et 95 SÉ-U (ailleurs): Intemes. résidents, fellows pré et post doctoral voir www.juns org pour détails. Copie simple: $22 \mathrm{SC}$ plus affranchissement et manutention. Toutes les communications et les manuscrits doivent être adressés à Journal Canadien des Sciences Neurologiques, P.O. Box 5456. Station A. Calgary. AB Canada T2H IX8, Par courrier: 709-7015 Macleod Trail SW. Calgary. AB Canada T2H 2K6. Téléphone (403) 229-9575; Fax (403) 229-1661. E-mail journal@ cjns.ong: Website: www.cjns.org DROITS D'AUTEUR 2004: THE CANADIAN JOURNAL OF NEUROLOGICAL SCIENCES INC. Tous droits réservés, Aucune partie de ce Journal ne peut être reproduite, sous quelque forme que ce soit, sans la l'authorisation du Journal Canadien des Sciences Neurologiques. Posté sous poste-publications: numéro de convention: 40007777: numéro d'enregistrement 09824. Port payé à Calgary, Alberta. Le Journal est cité et indexé dans Aquatic Sciences and Fishleries Abstracts, ASCA - Automatic Subject Citation Alert, Biological Abstracts, Chemical Abstracts, Curremt Advances in Ecological Sciences, Current Contents (Clinical Medicine and Life Sciences), Dent. Index, e-psyche, Exerpta Medica, Inder Medicus. Industrial Science Review, INIS Atomindex, Inpharma, Journal Watch Neurology. Industrial Science Review, INIS Atomindex, Inpharma, Journal Watch Neurolos. International Abstracts in Biological Sciences, Laboratory Hazards Bulletin.
Neturosciences Citation Index. Nutrition Abstracts. Nutrition Research Newsletter. Pharmaeconomics and Outcome News, Reactions Weekly, Referativnyi Zlurnal, Science Citation Index. Weed Abstracts.

Advertising representative/Représentant de publicité: Sally Gregg, Canadian Journal of Neurological Sciences 709 - 7015 Macleod Trail SW, Calgary, AB Canada T2H 2K6 $\mathrm{Tel}$ (403) 229-9575 Fax (403) 229-1661

E-mail: journal@cjns.org: Web Site: www.cjns.org

Printer/Imprimeur:

Sundog Printing Limited, 1311 Ninth Avenue SW, Calgary, Alberta $\mathrm{T} 3 \mathrm{C} 0 \mathrm{H} 9$

ISSN $0317-1671$ 


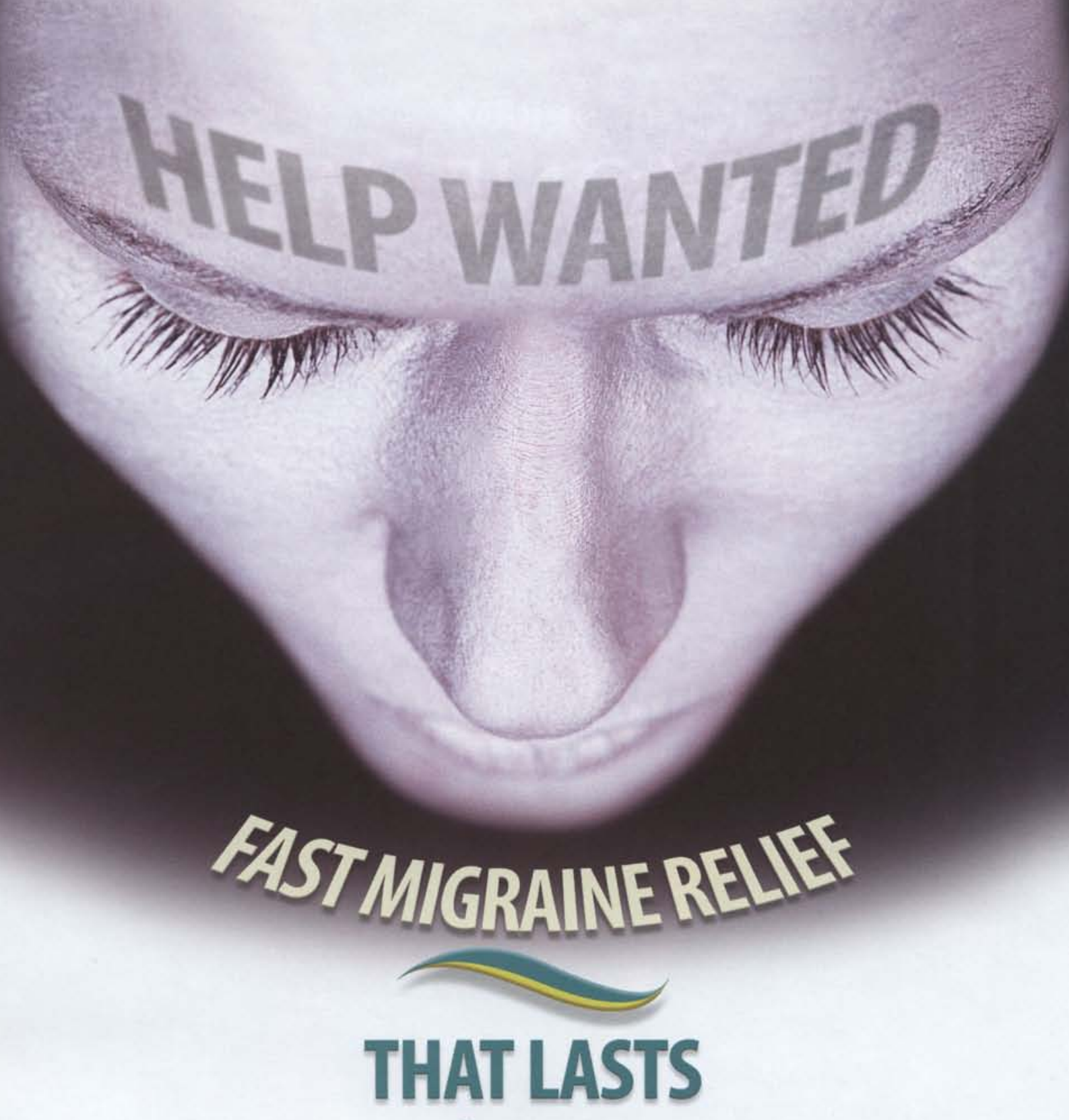

\section{Fast onset.}

Significant migraine pain relief attained as early as 30 minutes after treatment ${ }^{1 t}$

\section{Lasting relief.}

Demonstrated low incidence of migraine recurrence within 24 hours $^{27}$

\section{No recurrence seen in 4 out of 5 patients.}

After a single $12.5 \mathrm{mg}$ dose, $82 \%$ of responders had no recurrence of their migraine attack within 24 hours, in a clinical trial ${ }^{2 *}$

AXERT* (almotriptan malate) tablets are indicated for the acute treatment of migraine with or without aura in adults. AXERT* is not indicated for the prophylactic therapy of migraine or for use in the management of hemiplegic, ophthalmoplegic or basilar migraine. Safety and effectiveness of AXERT* have not been established for cluster headache, which presents in older, predominately male population.

Overall, in controlled dinical trials, only three side effects occuned in more than $1 \%$ of AXERT* patients and more frequently than in patients taking placebo: nausea (2\%), dy mouth (1\%) and paresthexia (1\%).

As with other triptans, AXERT * is contraindicated in patients with history, symptoms or signs of ischemic cardiac, cerebrovascular or peripheral vascalar syndromes, valvulat heart disease, cardiac arthythmias, uncontrolled typertension, ot in patients with other significant underlying cardiovascular disease. AXERI" should not be administered within 24 hours of treatment with another 5 -HT, aconist or an ergotamine-containing or ergot-type medication.

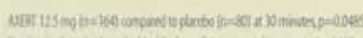

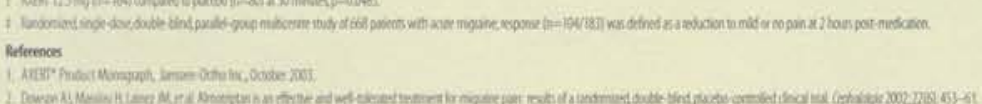

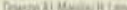

(10) JANSSEN-ORTHO

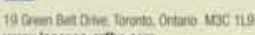

Ueened trom É Almirall

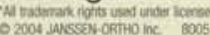

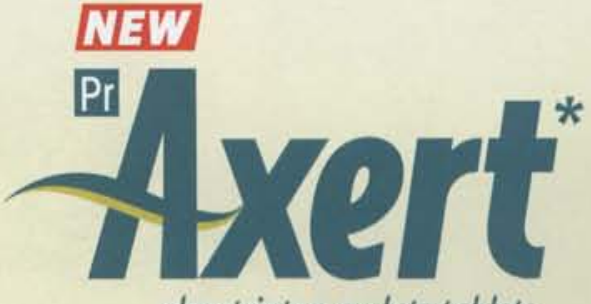

almotriptan malate tablets 
For the treatment of RRMS
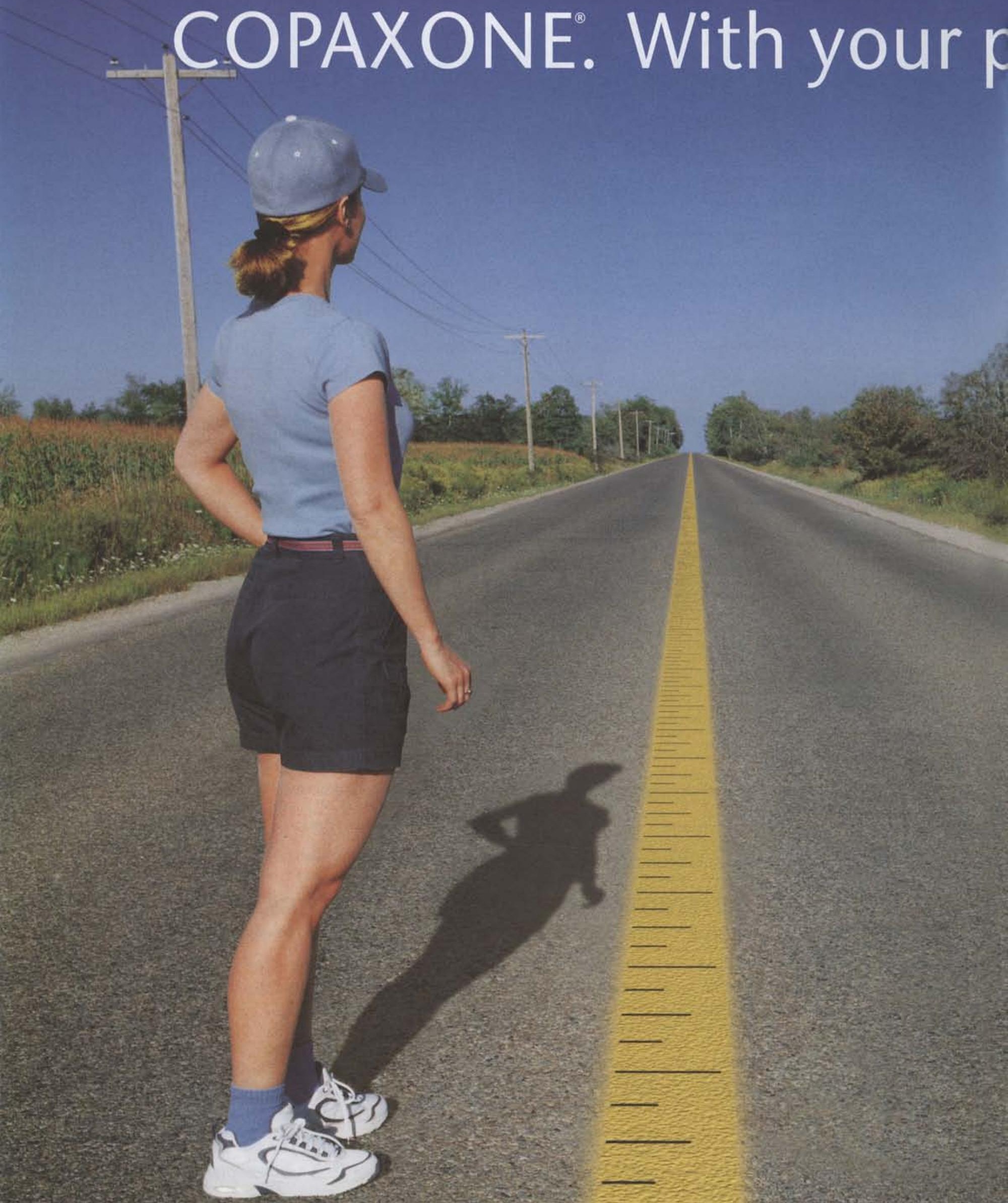
atients for the long run.

\section{Demonstrated impact on disability}

- COPAXONE--treated patients experienced a significant improvement in mean EDSS change: $123 \%$ treatment effect vs. placebo over 2 years $(-0.05\{n=125\} \text { vs. }+0.21\{n=126\}, p=0.023)^{1}$

\section{Reduced relapse rates*}

- $35 \%$ reduction at 9 months $(0.50\{n=113\} \text { vs. } 0.77\{n=115\} \text { placebo, mean, } p=0.0077)^{1}$

- $75 \%$ reduction at 2 years $(0.60\{n=25\} \text { vs. } 2.40\{n=25\} \text { placebo, mean, } p=0.005)^{1}$

${ }^{\star}$ Two independent studies

\section{Established safety profile}

- Demonstrated for over 7 years in clinical trials'

- No recommended monitoring of liver and thyroid function or complete blood count

COPAXONE' is indicated for use in ambulatory patients with RelapsingRemitting Multiple Sclerosis (RRMS) to reduce the frequency of relapses. The safety and efficacy of COPAXONE' in chronic progressive MS have not been established.

The most commonly observed adverse events associated with the use of COPAXONE" in controlled trials which occurred at higher frequency than placebo were: injection site reactions $(2.4-66.4 \%$ vs. $0-36.5 \%)$, vasodilation ( $27.2 \%$ vs. $11.1 \%)$, chest pain ( $26.4 \%$ vs. $10.3 \%)$, asthenia ( $64.8 \%$ vs. $61.9 \%)$, infection, pain, nausea $(23.2 \%$ vs. $17.5 \%)$, arthralgia ( $24.8 \%$ vs. $17.5 \%)$, anxiety and hypertonia ( $35.2 \%$ vs. $29.4 \%$ ).

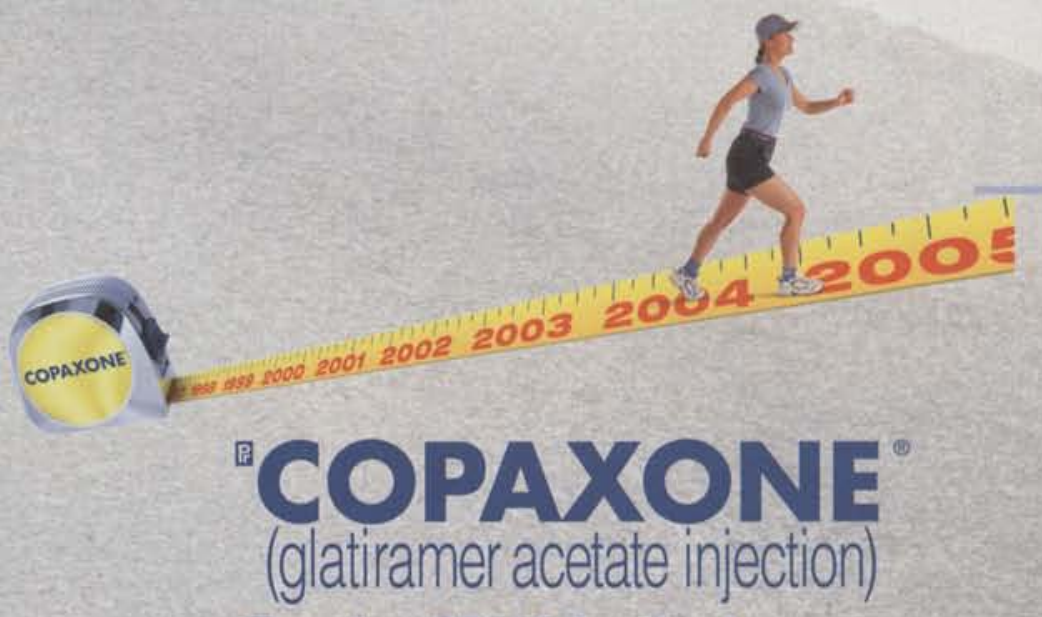

Treating RRMS for the long run. 



\section{EFFICACY ACROSS A BROAD RANGE OF SEIZURES.}

- TOPAMAX demonstrates efficacy in Partial Onset, Primary Generalized Tonic-Clonic, and Lennox-Gastaut Seizures

- Desirable seizure-free results were shown in both Adults $(19 \%)^{t}$ and Children $(22 \%)^{\ddagger}$ with Partial Onset Seizures

\section{NO EVIDENCE OF LIFE-THREATENING SIDE EFFECTS.}

- Like most antiepileptics, the most common side effects are CNS related, usually mild to moderate and transient $t^{\S 1}$

\section{ADULT PATIENTS MAY EXPERIENCE WEIGHT LOSS.}

- $73 \%$ of patients $(n=52)$ showed a mean weight decrease of $5.97 \mathrm{lb}$ (Interim analysis. Average duration 60 days)

- $96 \%$ of children in clinical trials ( $\geq$ one year) who lost weight showed resumption of weight gain in test period"1

\section{TODAY, THERE'S TOPAMAX.}

\section{B.I.D. DOSING WITH THE PATIENT IN MIND.}

- TOPAMAX is initiated and titrated to clinical response regardless of existing anticonvulsant therapy

- Tablets available on formulary"

NOW AVAILABLE

IN SPRINKLE CAPSULES
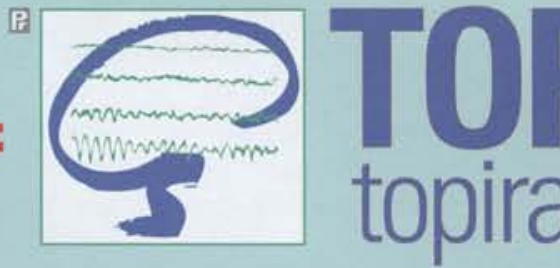
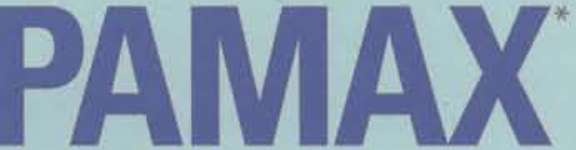

NDW INDICATED FOR CHILDREN

\section{HELPING PATIENTS MAKE MORE OF THEIR LIVES.}

"TOPAMAX" topiramate Tablets and Sprinkle Capsules: indicated as adjunctive therapy for the management of patients (adults and children two years and older) with epilepsy who are not satisfactorily controlled with conventional therapy. There is limited information on the use of topiramate in monotherapy at this time.

tOpen label. 20 week trial ( $\mathrm{n}=450$ Adults). 0 ptimal dosing was $300-350 \mathrm{mg} /$ day (Average $288 \mathrm{mg} /$ day).

t Open label trial for children ( $n=72$ ) treated for 23 months. Average dose of $10 \mathrm{mg} / \mathrm{kg} / \mathrm{dag}$.

CNS adverse events: Somnolence (30.1\%), diziness (28.3\%), ataxia (21.2\%), speech disorders $(16.8 \%)$, psychomotor slowing (16.8\%), nystagmus (15.0\%), paresthesia (15.0\%), nervousness (15.9\%), difficulty with concentration/attention (8.0\%), confusion (9.75). cepression (8.0\%), anorexia (5.3\%), language problems $(6.2 \%)$ and mood problems $(3.5 \%)$. In an audit of 1446 adults and 303 children, there appeared to be a similar pattern of adverse events.

The long-term effects of weight loss in pediatric patients are not knom.

tt limited use benefit: Ontario, Nova Scotia, New Brunswick, PEl. Full benefit: Quebec. Saskatchewan, British Columbia, Alberta, Manitoba.

Please refer to the TopaMaX Prescribing Information for complete prescribing details.

REFERENCES: 1. TOPAMAX topiramate Tablets and Sprinkle Capsules Product Monograph, May 11, 1999. 2. Kamin M, Kraut L, Olson W. Dose optinization of topinamate as add-on therapy in adults with treatment-resistant partial-onset seizures Meurology 1999:52 (Suppl 2):A525-526. 3. Glauser TA, Elternan R, Wyllie E et at Open label topiramate in paediatric partial epilepsy Epilepsio 1997:38 (Suppl 3):94. 4. Rosenfeld WE et at.Topiramate and concomitant weight loss. Epliepsio 1997:38 (Suppl 8):98. 


\section{INFORMATION FOR AUTHORS}

The Canadian Journal of Neurological Sciences publishes original articles in neurology, neurosurgery and basic neurosciences. Manuscripts are considered for publication with the understanding that they, or the essence of their content, have not been published elsewhere except in abstract form and are not under simultaneous consideration by another journal. A cover letter that states the above must accompany the submission. Articles undergo peer review. Manuscripts should be submitted to: Douglas Zochodne, M.D., Editor, Canadian Journal of Neurological Sciences, 7015 Macleod Trail SW, Suite 709, Calgary, AB, Canada T2H 2K6

\section{Manuscript Preparation}

- Submit five high quality copies of the manuscript and original illustrations. Papers will be accepted in English or French. Manuscripts must be double spaced throughout including references, tables and legends for illustrations. Margins of at least $25 \mathrm{~mm}$ should be left on all sides.

- After a paper has been reviewed, the author will be requested to submit four copies of the revised manuscript, including illustrations. Supply a computer diskette ( $31 / 2^{\prime \prime}$ size) containing the article saved in an RTF format. Identify clearly first author's name, file name, word processing program and version, and system (i.e. PC or Mac). Clearly indicate the order and importance of headings.

- For detailed instructions regarding style and layout refer to "Uniform requirements for manuscripts submitted to biomedical journals". Copies of this document may be obtained on the website www.icmje.org, but the main points are summarized here. Articles should be submitted under conventional headings of introduction, methods and materials, results, discussion, but other headings will be considered if more suitable. Clinical trials must be reported in Consort format (www.cjns.org). Pages of text should be numbered consecutively.

- A title page should identify the title of the article which should be no more than 80 characters including spaces; name of institution(s) from which the work originated; and the name, address, telephone, and fax number of the corresponding author.

- Abstract Original Articles should be accompanied by an abstract of 250 words or less on a separate page, preferably in English and French, although the Journal will provide translation if required. Abstracts of original articles should consist of four paragraphs headed: Background (or objective), Methods, Results and Conclusions. Review articles should be accompanied by an abstract of 150 words or less.

- Acknowledgements including recognition of financial support should be typed on a separate page at the end of the text.

- The SI system (système international d'unités) should be used in reporting all laboratory data, even if originally reported in another system. An Ethics approval statement must be provided, if applicable. Temperatures are reported in degrees celsius. English language text may use either British or American spelling, but should be consistent throughout.

- References should be numbered in the order of their citation in the text. Those cited only in tables and legends for illustrations are numbered according to the sequence established by the first identification in the text of a particular table or illustration. Titles of journals should be abbreviated according to the style used in Index Medicus. References should list the names of up to five authors; if there are more, cite the first three, then et al. Provide the full title, year of publication, volume number and inclusive pagination for journal articles. For any reference cited as "in press", five copies of the article must accompany the author's manuscript. Do not reference unpublished or "submitted" papers; these can be mentioned in the body of the text and authors must provide five copies of "submitted" manuscripts. Avoid "personal communications" and, if necessary, include them in the body of the text, not among the references. Reference citations should not include unpublished presentations or other non-accessible material. Books or chapter references should also include the place of publication and the name of the publisher. Examples of correct forms of reference follow:

Journals

Yang JF, Fung M, Edamura R, et al. H-Reflex modulation dưring walking in spastic paretic subjects. Can J Neurol Sci 1991; 18: 443-452.

Chapter in a book

McGeer PL, McGeer EG. Amino acid neurotransmitters. In: Siegel GJ, Albers RW, Agranoff BW, Katzman R, eds. Basic Neurochemistry. Boston: Little, Brown \& Co., 1981: 233-254.

- Illustrations Submit five original sets of illustrations. We will not return illustrations; therefore, authors should keep negatives for all photographs. Submit high quality glossy black and white photographs preferably $127 \times 173 \mathrm{~mm}\left(5^{\prime \prime} \times 7^{\prime \prime}\right)$. This includes graphs and diagrams. Do NOT send photocopies of illustrations. Original artwork and radiographs should not be submitted. The additional cost of coloured illustrations must be borne by the author; quotations are available upon request from the Journal office. Identify each figure with a label at the back indicating top, figure number and first author. Letters and arrows applied to the figures to identify particular findings should be professional appliques suitable for publication. Photomicrographs should include a calibration bar with a scale indicated on the figure or in the legend. Legends for illustrations should be typed on a separate page from the illustrations.

- Tables Type tables double-spaced on pages separate from the text. Provide a table number and title for each. Particular care should be taken in the preparation of tables to ensure that the data are presented clearly and concisely. Each column should have a short or abbreviated heading. Place explanatory matter in footnotes, not in the heading. Do not submit tables as photographs.

- Review articles on selected topics are also published. They are usually invited, but unsolicited reviews will be considered. It is recommended that authors intending to submit review articles contact the Editor in advance.

- Letters to the Editor concerning matters arising in recent articles are welcome. Letters should be limited to two double-spaced pages and may include one illustration and a maximum of four references.

- Permissions and Releases Any non-original material (quotations, tables, figures) must be accompanied by written permission from the author and the copyright owner to reproduce the material in the Journal. Permission must be for print and electronic media. Photographs of recognizable persons must be accompanied by a signed release from the legal guardian or patient authorizing publication. Case reports should include signed consent from the patient being reported.

- Conflict of Interest Authors who have non-scientific or non-academic gain whether it be financial or other from publishing their article are responsible for declaring it to the Editor. Any financial interest, research grant, material support, or consulting fee associated with the contents of the manuscript must be declared to the Editor. These guidelines apply to each author and their immediate families. Conflicts of interest are not necessarily wrong nor do they necessarily change the scientific validity of research or opinion, but the Journal and readers should be aware of the conflict. If the Editor considers the conflict to compromise the validity of the paper, it will not be accepted for publication. Authors, editorial staff and reviewers are asked to declare any relationship that would be considered as a conflict of interest whether or not they believe that a conflict actually exists. Information that the Journal receives about conflict or potential conflict will be kept confidential unless the Editor or Associate Editor considers it to be important to readers. Such conflicts will be published in the author credits or as a footnote to the paper, with knowledge of the authors. 


\section{Neutralizing antibodies (NAbs) may significantly impact IFNß's ability to bind to receptors and initiate an immunomodulatory process.}

\section{AVONEX ${ }^{\circledR}$ has demonstrated the lowest incidence of NAbs.}

- AVONEX treated patients had the lowest risk of becoming persistent NAb-positive; $2 \%$ of patients versus $15 \%$ and $31 \%$ for Rebif ${ }^{\odot}$ (IFNB-1a $22 \mu \mathrm{g}$ ) and Betaseron ${ }^{\otimes}$ (IFNB-1b) respectively (Betaseron ${ }^{\circ}$ vs AVONEX $p=0.001$, Betaseron ${ }^{\circ}$ vs Rebif ${ }^{\oplus} p=0.19$, Rebif ${ }^{\oplus}$ vs AVONEX $\left.p=0.04, n=125\right) .^{2}$

- The majority of NAbs usually appear during the first 12 months after initiation of IFN 3 therapy (ranging from 3 to 18 months). ${ }^{2,5}$

\section{Once-a-week AVONEX - Efficacy that Lasts}

$\mathbf{3 7} \%$ reduction in probability of disability progression at 2 years $(21.9 \%$ vs. $34.9 \% ; p=0.02){ }^{n .5}$

$32 \%$ reduction in annual exacerbation rate over 2 years ( 0.61 vs. $0.90 ; p=0.002) .{ }^{.5}$

$\mathbf{5 5 \%}$ reduction in whole brain atrophy progression in year $2(-0.233 \text { vs. }-0.521 ; p=0.03)^{0.6}$

$\mathbf{8 9} \%$ reduction in $\mathrm{Gd}$-enhanced lesions in patients with enhancement at baseline ( 0.11 vs $0.50 ; p=0.041) .{ }^{t .7}$

AVONEX is indicated for the treatment of relapsing forms of MS. AVONEX is generally well tolerated. The most common side effects associated with treatment are flu-like symptoms (muscle ache [myalgia], fever, chills, and asthenia). AVONEX should be used with caution in patients with depression and in patients with seizure disorders. Patients with cardiac disease should be closely monitored. Routine periodic blood chemistry and hematologic tests are recommended during treatment with AVONEX.
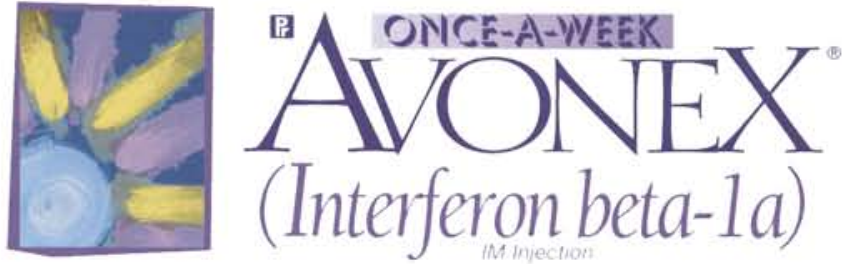

EFFICACY THAT LASTS

As demonstrated in 2 years of clinical trials

\& Comparative clinical significance has not been established

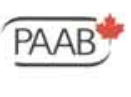
१ा Kaplan-Meier methodology. AVONEX $n=158$, placebo $n=143$ * * AVONEX $n=85$, placebo $n-87$ As measured by brain parenchyrmal fraction, AVONEX $n=68$. placebo $n=72$

AVONEX $n=44$, placebo $n=44$. The exact relafionsthip belween MRI findings and clinical status is unknown. Biogen Canada is a trademlark of Biogen. Inc. AVONEX is a registered trademark ol Biogen, Inc Rebif is a registered trademark of Serono Canada Inc. Betaseron is a registered trademark of Betlex Canada Inc

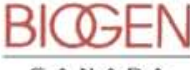




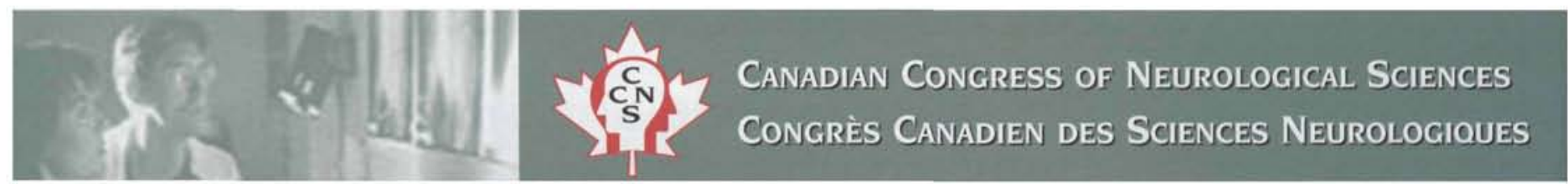

Home I Contact I Site Map I Search

CCNS INFORMATION

About CCNS

Become a member

Residents

Meetings \& Events

Canadian Brain \&

Nerve Health Coalition

Affiliates \& Associates

Maintenance of Certification

Canadian Journal of

Neurological Sciences

Links

\section{MEMBERS' CENTRE}

CME

News \& Views

The CCNS

CCNS Societies

Residents

Canadian Journal of

Neurological Sciences

\section{Visit the new}

\section{Canadian Congress of Neurological}

\section{Sciences}

website (www.ccns.org)

The CCNS website has a new look and new features.

- Check out the home page for a new feature on "Pioneers in Canadian Neurology".

- Visit the site to get the latest information on the annual scientific meeting, and register online.

- Planning a CME event? Look up the comprehensive Maintenance of Certification section.

- Not a member? Visit the "Become a Member" section, read about member benefits and download an application form.

- Are you a resident or Fellow? Visit the "Residents and Fellows" section for information just for you.

\section{Log in to the Members' Centre* for Online CME}

Society members can log in to the Members' Centre:

- To earn MOC credits online - take the quizzes relating to articles in the Canadian Journal of Neurological Sciences (CJNS).

- To view other CME

Residents - Interested in a Fellowship?

- Visit the Resident's Section of the Members' Centre for a list of fellowship opportunities

Can't find your username and password? Contact the CCNS office at (403) 229-9544 or e-mail brains@ccns.org.

*Members are members of the Canadian Neurological Society, the Canadian Neurosurgical Society, the Canadian Society of Clinical Neurophysiologists or the Canadian Association of Child Neurology. See the CCNS website at www.ccns.org for membership information. 


\section{ProvisIONAL Program}

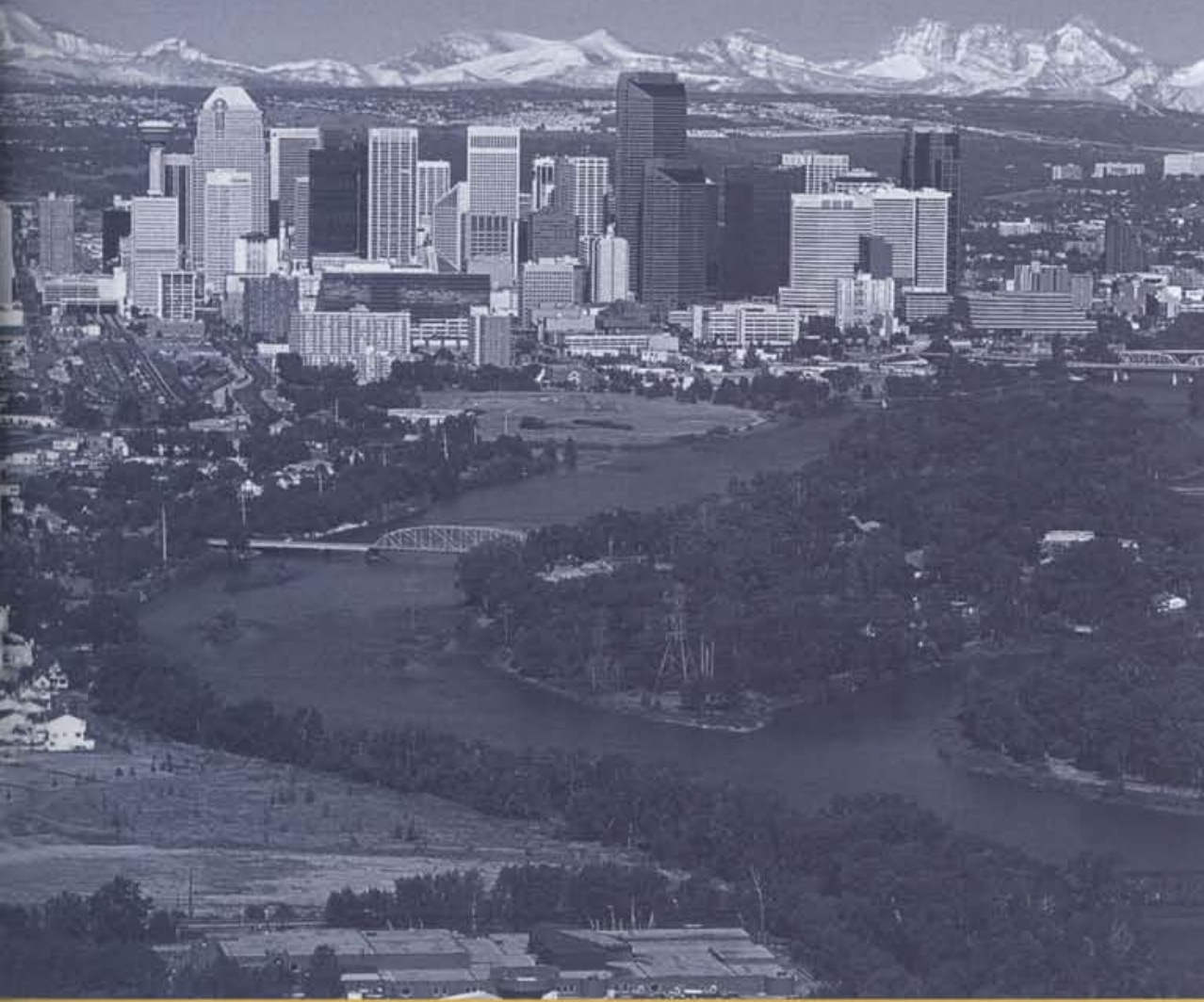

Canadian Congress of Neurological Sciences

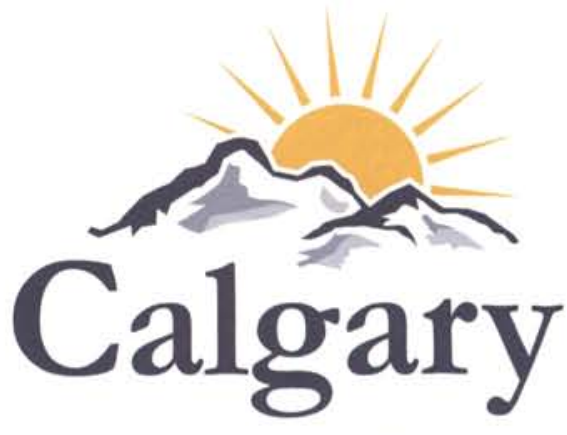

CCNS $\cdot$ CCSN

June 8-12 juin 2004
Tuesday June 8, 2004

Pre-Congress Courses

08:00-17:30 Neurobiology Review Course

09:00-16:00 ALS-Strategies for Quality Life/Quality Care

18:00-21:00 Movement Disorders Video Session

18:00-21:00 Headache Case Studies

\section{Wednesday, June 9, 2004}

08:00-17:30 Complex Spinal Neurosurgery Course

08:00-12:00 Brain Tumour Course - Advances in Neuro-Oncology

08:00-12:00 Epilepsy Course

08:00-12:00 Update on Electromyography and its Clinical

$$
\text { Applications }
$$

13:30-17:30 Alzheimer's Disease Course

13:30-17:30 Radiosurgery Course - Current Role in Neurosurgical

Practice

13:30-17:30 Movement Disorders Course - Cognitive and Behavioral Aspects of Parkinson's Disease

13:30-17:30 EEG Course

18:00-20:00 Welcome Reception
Thursday, June 10, 2004

08:30-10:30 Plenary Session I: Neurology and Neurosurgery in the Developing World

11:00-13:00 Platform Session

13:00-14:30 Poster Session

14:30-16:00 Platform Session

16:00-17:30 Grand Rounds

17:30-19:00 Poster Tours

\section{Friday, June 11, 2004}

08:30-10:30 Plenary Session II: New Directions in the Neurosciences

11:00-13:00 Platform Session

13:00-14:30 Poster Session

14:30-16:30 Plenary Session III: Risk Reduction in the Clinical Neurosciences

18:00 Social Night

\section{Saturday, June 12, 2004}

08:00-10:00 Neurocritical Care Mini-Symposium - Traumatic Brain Injury

08:00-10:00 What's New in Neurology? Mini-symposium

08:00-10:00 How I do it ... Neurosurgery. Mini-symposium

08:00-17:30 Child Neurology Day: Pediatric Brain Injury

10:30-17:00 Stroke Symposium

10:30-17:30 Multiple Sclerosis 


\section{C.}

PHARMACOLOGIC CLASSIFICATION:

\section{Angiotensin Converting Enzyme Inhibitor}

ACTION AND CUNICAL PHARMACOLOGY

ALIACE (ramipiril) is an angoitensin corverting enzyme (ACE) inhibitor.

Following oral administration, ALIACE is rapidly hycrolyzed to ramipriat, its principal active metabolite.

INDICATIONS AND CLINICAL USE: Essential Hypertension. ALTACE (ramipril) is indicated in the treatment of essential hypertension. It may be used alone or in association with thiazide diuretics. ALTACE should normally be used in patients in Whom treatment with a diuretic or a beta-blocker was found ineffective or has been associated with unaccepteble adverse effects. ALTACE can also be tried as an initial
agent in those patients in whom use of diuretics and/or beta-blockers are contraindicated or in patients with medical conditions in which these drugs frequently
cause serious adverse effects. The safety and efficacy of ALTACE in renovascular hypertension have not been established and therefore, its use in this condition is no antihyoertensive agents other than thiazide diuretics have not been established. Ireatment Following Acute Mvocardial Infarction

with signs of left ventricular dysfunction to improve sunvival abe patients with signs of left ventricular dystunction to improve survival and reduce
hospitalizations for heart fallure. Sufficient experience in the treatment of patients with severe (NYHA class II) heart failure immediately after myocardial infarction is not yet available. (See WARNINGS - Hypotension.

MANAGEMENT OF PATIENTS AT INCREASED RISK OF CARDIOVASCULAR EVENIS: ALTACE may be used to reduce the risk of myocardial inlarction, stroke or cardiovascular death in patients over 55 years of age who are at high risk of peripheral artery disease, or diabetes that is accompanied by at least one other cardiovascular risk factor such as hypertension, elevated total cholesterol levels, low high density lipoprotein levels, cigarette smoking, or documented microalbuminuria
The incidence of the primary outcome (composite of myocardial infarction, stroke and The incidence of the primary outcome (composite of myocardilal infarction, stroke and
death from cardiovascular causes) was reduced from $17.8 \%$ in the placebo-treated death from cardiovascular causes) was reduced
group to $14.0 \%$ in the ramipril-treated group.

GENERAL: In using ALTACE consideration should be given to the risk of angioedema (see WARNINGSS), When used in pregnancy during the second and third trimesters, ACE inhibitors can cause injury or even death of the developing
fetus. When pregnancy is detected ALTACE should be discontinued as soon as pATIENT).

CONTRAINDICATIONS: ALTACE (ramipril) is contraindicated in patients who are hypersensitive to this drug, or to any ingredient in the formulation, or in those patients

WARNINGS: Angieedema Angioedema has been reported in patients with ACE inhibitors, including ALTACE (ramipril). Angioederma associated with laryngeal glottis Occurs. ALTACE should be discontinued immediately, the patient treater appropriately in accortance with accepted medical care, and carefully observed until the swelling disappears. In instances where swelling is confined to the face and lips, the condition generally resolves without treatment, although antihistamines may be useful in relieving symptoms. Where there is involvement of tongue, glottis, or larynx, likely to cause airway obstruction, appropriate therapy (including, but not limited to
0.3 to $0.5 \mathrm{~mL}$ of subcutaneous epinephrine solution $1: 1000$ ) should be administered promptly (SEe ADVERSE REACTIONS).

The incidence of angioedema during ACE inhibitor therapy has been reported to be higher in black than in non-black patients. Patients with a history of angioedema
unrelated to ACE inhibitor therapy may be at increased risk of angioedema while unrelated to ACE inhibitor therapy may be at increased
receiving an ACE inhibitor (see CONTRANDICATIONS).

Hypotension: Symptomatic hypotension has occurred after administration of ALTACE, usually after the first or second dose or when the dose was increased. It is more likely to occur in patients who are volume depleted by diuretic therapy, dietary salt
restriction, dialysis, diarnhea, or vomiting. In patients with ischemic heart disease or restriction, dialysis, diarrhea, or vomiting. In patients with ischemic heart disease or
cerebrovascular disease, an excessive fall in blood pressure could result in a myocardial infarction or cerebrovascular accident (see ADVERSE AEACTIONS). Because of the potential fall in blood pressure in these patients, therapy with ALIACE closely for the first weeks of treatment and whenever the dose of AlTACE is increased In patients with severe congestive heart failure, with or without associated renal insufficiency, ACE inhibitor therapy may cause excessive hypotension and has been associated with olig

Ithypotension occurs, the pabent should be placed in a supine position and, if necessary. receive an intravenous infusion of $0.9 \%$ sodium chloride. A transient hypotensive response may not be a contraindication to further doses which usually can be given
without difficulty once the blood pressure has increased after volume expansion in hypertensive petients Hine blood pressure has increased after volume expansion in hypertensive pabients. However, lower doses of ALTACE and/or reduced concomitant
diuretic therapy should be considered. in patients receiving treatment following acute diuretic therapy should be considered. In patients receiving treatment following acute myocardial infarction, consideration should be given to discontinuation of ALTACE(SECE
ADVERSE REACTIONS - Treatment Following ACute Myocardial Infarction, DOSACE AND ADUM ISTRATON - Treatment Following ACute Myocendial intaction.

Neutropenia/Agranulocytosis: Agranulocytosis and bone marrow depression have been caused by ACE inhibitors. Several cases of agranulocytosis, neutropenia or
leukopenia have been reported in which a causal relationship to ALTACE cannot be excluded. Current experience with the drug shows the incidence to be rare. Periodic monitoring of white blood cell counts should be considered, especially in patients with collagen vascular disease and/or renal disease. Use in Pregnancy: ACE inhibitors can cause fetal and neonatal morbidity and mortality when administered to pregnant pregnancy is detected, ALTACE should be discontinued as soon as possible.

PRECAUTIONS: Renal Imoairment: As a consequence of inhibiting the reninsusceptible individuals. In patients whose renal function may depend on the activity of the renin-angiotensin-aldosterone system, such as patients with bilateral renal artery stenosis, unilateral renal artery stenosis to a solitary kidney, or severe congestive heart failure, treatment with agents that inhibit this system has been
associated with oliguria, progressive azotemia, and rarely, acute renal fallure and/or associated with oliguria, progressive azotemia, and rarely, acute renal failure and/or
death. In susceptible patients, concomitant diuretic use may further increase risk. death. In susceptible patients, concomitant diuretic use may further increase risk.
Use of ALTACE should include appropriate assessment of renal function. ALTACE should be used with caution in patients with renal insufficiency as they may require reduced or less hrequent doses (see DOSAGE AND ADMNITRAnON. Clase appropriate in patients with renal insufficiency.

Anaphylactoid Reactions during Membrane Exposure: Anaphylactoid reactions have been reported in patients dialyzed with high-flux membranes (e.g. polyacrylonitrile
[PAN]) and treated concomitantly with an ACE inhibitor. Dialysis should be stopped immediately if symptoms such as nausea, abdominal cramps, burning, angioedema, shortness of breath and severe hypotension occur. Symptoms are not relieved by type of dlalysis membrane or a different class of antihypertensive agents.

Anaghylacteid Reactions during Desensitization: There have been isolated reports of patients experiencing sustained life threatening anaphylactoid reactions while wasps) ven inhibitors during desensitization treatment with hymenoptera (bees, inhibitors were temporarily witheld for at least 24 hours, but they have reappeared upon inadvertent rechallenge.

Hyperkalemia and Potassium-Sparing Duretics: Elevated serum potassium (greater clinical trials treated with ALTACE. In most cases $1 \%$ of hypertensive patients in resolved despite continued therapy. Hyperkalemia was not a cause of discontinuation of therapy in any hypertensive patient. Risk factors for the development of hyperkalemia may include renal insufficiency, diabetes mellitus, and the concomitant use of agents to treat hypokalemia or other drugs associ
potassium (see PRECAUTIONS - Drug Interactions).

Surgery/Anesthesia: In patients undergoing surgery of anesthesia with agents producing hypotension, ALTACE may block angiotensin $\|$ formation secondary to
compensatory renin release. If hypotension occurs and is considered to be due to this
mechanism, it may be corrected by volume repletion.

Aortic Stenosis: There is concem, on theoretical grounds, that patients with aortic stenosis might be at particular risk of decreased coronary perfusion when treat

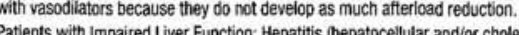

Patients with Impaired Liver Function; Hepatitis (hepatocellular and/or cholestatic), elevations of liver enzymes and or serum bilirubin have occurred during therapy with
ACE inhibitors in patients with or without pre-existing liver abnormalities. In most cases the changes were reversed on discontinuation of the drug.

Elevations of liver enzymes and/or serum bilirubin have been reported with ALTACE see ADVERSE REACHONS). Should the patient receiving ALTACE experience any is recommended that a full set of liver function tests and any other necessary investigations be carried out. Discontinuation of ALTACE should be considered when appropriate. There are no adequate studies in patients with cirrhosis and/or liver dystunction. ALTACE should be used with particular caution in patients with preexisting liver abnormalities. In such patients baseline liver function tests should be metabolic effects should apply.

Nursing Mothers: ingestion of a single $10 \mathrm{mg}$ oral dose of ALTACE resulted in undetectable amounts of ramipril and its metabolites in breast milk. However, from single doses, ALTACE should not be administered to nursing mothers.
froctions

Pediatric Use; The safety and effectiveness of ALTACE in children have not been established; therefore use in this age group is not recommended.

Use in Elderly : Although clinical experience has not identified differences in response older individuals cannot be ruled out.

Patient Alertness: ALTACE may lower the state of patient alertness and/or reactivity, particularly at the start of treatment (see ADVERSE REACTIONS).

Cough: A dry, persistent cough, which usually disappears only after withdrawal or considered as part of the differential diagnosis of cough.

Drug Interactions: Concomitant Diuretic Therapy: Hypotension may result but can be minimized by discontinuing diuretic or increasing salt intake prior to ramipril treatment and/or reducing initial dose. Agents increasing serum ootassium: Use

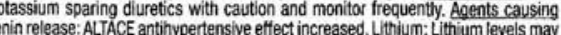
The increased.Administer lithum with caution and monitor leveis frequently. Antacids: affected. Digoxin: No change in ramipril, ramiprilat or digoxin serum levels. Warfarin: The co-administration of ALTACE with warfarin did not alter the anticoagulant effects.
Acenocoumarol: No significant changes. Non-steroidal anti-inflammatory agents ACenocoumarol: No significant changes. Non-steroidal anti-inflammatory agents
NSAIDY: The antihypertensive effects of ACE inhibitors may be reduced with

ADVERSE REACTIONS: Essential Hvoertension, Serious adverse events occurring in North American placebo-controlled clinical trials with ramipril monotherapy in hypertension ( $n=972$ ) were: hypotension $(0.1 \%)$; myocardial infarction $(0.3 \%)$;
cerebrovascular accident $(0.1 \%)$; edema $(0.2 \%)$; syncope $(0.1 \%)$. Among all North American ramipril patients $(n=1,244)$, angioedema occurred in patients treated with ramiprit and a diuretic $(0.1 \%)$. The most frequent adverse events occurring in these trials with ALTACE monotherapy in hypertensive patients ( $n=651$ ) were: headache (15.1\%); dizziness (3.7\%); asthenia (3.7\%); chest pain (2.0\%); nausea (1.8\%); peripheral edema (1.8\%); somnolence (1.7\%); impotence (1.5\%); rash (1.4\%), vents was required in 5 patients $(0.8 \%)$. In placebo-controlled trials, an excess of pper respiratory infection and flu syndrome was seen in the ramipril group. As these studies were carried out before the relationship of cough to ACE inhibitors was
recognized, some of these events may represent ramipril-induced cough in a later recognized, some of these events may represent ramipril-induced cough. In a later about $4 \%$ of these patients requiring discontinuation of treatment. Approximately $1 \%$ rials $(n=972)$ have required discontinuation because of cough.

Treatment Following Acute Mvocardial Infarction

overse events (except laboratory abnormalities) in a controlled clinical trial of postAMI patients with clinical signs of heart fallure considered possibly/probabily related hypotension (10.7\%); increased cough $(7.6 \%)$; dizziness $/ v e r t i g o(15.6 \%)$ nausea/vomiting (3.8\%): angina pectoris (2.9\%), postural hypotension (2.2\%) syncope $(2.1 \%$ ); heart failure $(2.0)$; severe ressistant heart failure $(2.0 \%)$; my ocardial (1.2\%); abnormal chest pain (1. $1 \%$ ); diarrhea (1.1\%). isolated cases of death have been reported with the use of ramipril that appear to be related to hypotension
(including first dose effects), but many of these are difficult to differentiate from progression of underlying disease (see WARNiNGS - Hypotension). Discontinuation of therapy due to adverse reactions was required in $368 / 1,004$ post-AMit patien Clinical Laboratory Test Findings: increased creatinine; increases in blood urea of liver enzymes, serum bilirubin, uric acid, blood glucose; proteinuria and significan creases in serum potassium.

Essential Hypertension: Dosage of ALTACE (ramipril) must be individualizer Initiation of therapy requires consideration of recent antitiypertensive drug treatment, the extent of blood pressure elevation and salt restriction. The dosage

Monotherapy: The recommended initial dosage of AUACE in patients not on diuretics is $2.5 \mathrm{mg}$ once daily. Dosage should be adfiusted according to blood pressure response, generally, at intervals of at least two weeks. The ussa:

in some patients treated once dalily, the antihypertensive effect may diminish towards the end of the dosing interval. This can be evaluated by measuring blood pressure 24 hours. If tit is not, either twice daily administration with the same total daily dose, or an increase in dose should be considered. If blood pressure is not controlled with ALTACE alone, a diuretic may be added. After the addition of a diuretic, it may be possible to reduce the dose of ALTACE.

Concomitant Diuretic Theragy: Symptomatic hypotension occasionally may occu being treated with a diuretic. The diuretic should, If possible, be discontinued tor two to three days before beginning therapy with ALTACE to reduce the likelihood of hypotension (see WARNNNGS. If the diuretic cannot be discontinued, an inital dose
of $1.25 \mathrm{mg}$ of ALTACE should be used with careful medical supervision for several
hours and until blood pressure has stabilized. The dosage of ALTACE should subsequently be titrated (as described above) to the optimal response.

Use in Renail Impairment for patients with a creatinine clearance below $40 \mathrm{~mL} / \mathrm{min} /$ $1.73 \mathrm{~m}^{2}$ (serum creatinine above $2.5 \mathrm{mg} / \mathrm{dL}$ ), the recommended initial dose is $1.25 \mathrm{mg}$ of ALTACE once daily. Dosage may be titrated upward unti blood pressure mpaimen or to a maximum total daily dose of $5 \mathrm{mg}$. In patients with severe renal dose of $2.5 \mathrm{mg}$ of ALTACE should not be exceeded.

\section{reatment Following Acute Myocardial Infarction:}

Thation of therapy requires consideration of concomitant medication and baseline theosure and should be instututed under close medical supervision, usualy in a hospital, three to ten days following an acute myocardial infarction in

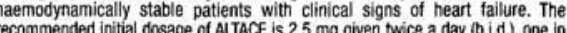
recommended initial dosage of ALTACE is $2.5 \mathrm{mg}$ given twice a day (b.id.), one in
the morning and one in the evening. If tolerated, and depending on the patient's The maximum daily dose of ALTACE should not exceed 5 mo twice daily the initial dose of ALTACE the pat tent should be observed under medical supenvision 作 hour. If a patient becomes hypotensu at this dosage it is recommented than the dosage be lowered to $1.25 \mathrm{mg}$ b.i.d. following effective management of the hypotension. (see WARNINGS - Hypotension).

atients who have been fluid or salt depleted, or treated with diuretics are at an increased risk of hypotension (see WARNINGS - Hypotension). An excessive tall in Lood pressure may occur particularly in the following: after the initial dose of ALIACE; diuretic and/or when increasing the dose of the concomitant diuretic. It appropriate, the dose of any concomitant diuretic should be reduced which may diminish the likelihood of hypotension (see PRECAUTIONS - Drug Interactions). Consideration
should be given to reducing the initial dose to $1.25 \mathrm{mg}$ of ALIACE in these patients. Use in Renal Impaiment In patients with impaired renal function (creatinine clearance of $20.50 \mathrm{~mL} / \mathrm{min} / 1.73 \mathrm{~m}^{2}$ body surface area), the initial recommended dosage is generally 1.25 m of ALTACE once daily. This dosage may be increased with
caution up to $1.25 \mathrm{mg}$ of ALTACE twice daily, depending upon clinical response and tolerability

Insufficient data is available conceming the use of rami pril following acute myocardial infarction in patients with heart failure and severe renal failure. (see ACTION ANO
CLINCAL PHARMACOLOGY - Pharmacokinetics and Metabolism, PRECAUTIONS Renal Impairment).

Use in Hepatic Impairment: Insufficient data is available concerning the use of ramipn! dysfunction. Dose reduction and careful monitoring of these patients is required (see ACTIONS AND CLINICAL PHARMACOLOGY - PharmaC

Management of Patients at Increased Risk of Cardiovascular Events: Recommended initial dose: $2.5 \mathrm{mg}$ of ALTACE once daily. Depending on the after one week of treatment and - after another three weeks - to increase it to $10 \mathrm{mg}$. Usual maintenance dose: 10 mg of ALTACE daily (see ACTION AND CLINICAL PHARMACOLOGY, WARNINGS and PRECAUTIONS). Dosage recommendations for special risk groups such as patients with renal or hepatic impairment, or at an followed as previously described (see WARMiNGS and PRECAUTIONS)

DOSAGE FORM

ALTACE (ramipril) capsules $1.25 \mathrm{mg}, 2.5 \mathrm{mg}, 5.0 \mathrm{mg}$, and $10.0 \mathrm{mg}$ contain the medicinal ingredient ramipril in quantities of $1.25 \mathrm{mg}, 2.5 \mathrm{mg}, 5.0 \mathrm{mg}$, and $10.0 \mathrm{mg}$ respectively. The qualitative formulation for all potencies of ALTACE is: ramipril, pregelatinized starch NF (as filler, gliding agent and disintegration agent) and empty gelatin capsules. Empty gelatin capsules for all potencies of ALIACE are

\begin{tabular}{|c|c|c|}
\hline POTECY & CAP & Boor \\
\hline $1.25 \mathrm{mg}$ & $\begin{array}{l}\text { Yellow iron oxide } \\
\text { Titanium dioxide }\end{array}$ & Titanium dioxide \\
\hline $2.5 \mathrm{mg}$ & $\begin{array}{l}\text { Yellow iron oxide } \\
\text { FD \& C red no. } 3 \\
\text { Titanium dioxide }\end{array}$ & Titanium dioxide \\
\hline $5.0 \mathrm{mg}$ & $\begin{array}{l}\text { FD \& C blue no. } 2 \\
\text { FO \& C red no. } 3 \\
\text { Titanium dioxide }\end{array}$ & Titanium dioxide \\
\hline $10.0 \mathrm{mg}$ & $\begin{array}{l}\text { FD \& C blue no. } 2 \\
\text { FD \& C red no. } 3 \\
\text { Black iron oxide } \\
\text { Titanium dioxide }\end{array}$ & Titanium dioxide \\
\hline
\end{tabular}

b) Stability and storage recommendations

Store ALTACE (ramiprili) in original container at room temperature, below $25^{\circ} \mathrm{C}$ and not beyond the date indicated on the container.

$0.25 \mathrm{mg}$ (white/yellow)

- $10.0 \mathrm{mg}$ (whitedolue)

ALTACE capsules $1.25 \mathrm{mg}, 2.5 \mathrm{mg}, 5.0 \mathrm{mg}$ and $10.0 \mathrm{mg}$ are packaged in cartons of 30 ( $2 \times 15$ blister-packed) capsules. Bottles of 100 capsules and 500 capsules also

Product monograph available upon request.

References:

1. ALTACE Product Monograph. 2. The Heart Outcomes Prevention Evaluation Study Investigators (HOPE) Trial. Effects of an angiotensin-converting-enzyme inhibitoc,
ramipril, on cardiovascular events in high-risk patients. $N$ Engl $J$ Med ramipril, on cardiov $2000 ; 342$ (3): $145-53$.
20.

(3) Registered trade-mark of Aventis Group. Used under licence by (R⿺D) 


\section{PORTRAIT OF A FAMILY History}

\section{History Doesn’t Have to Repeat ITSElf}
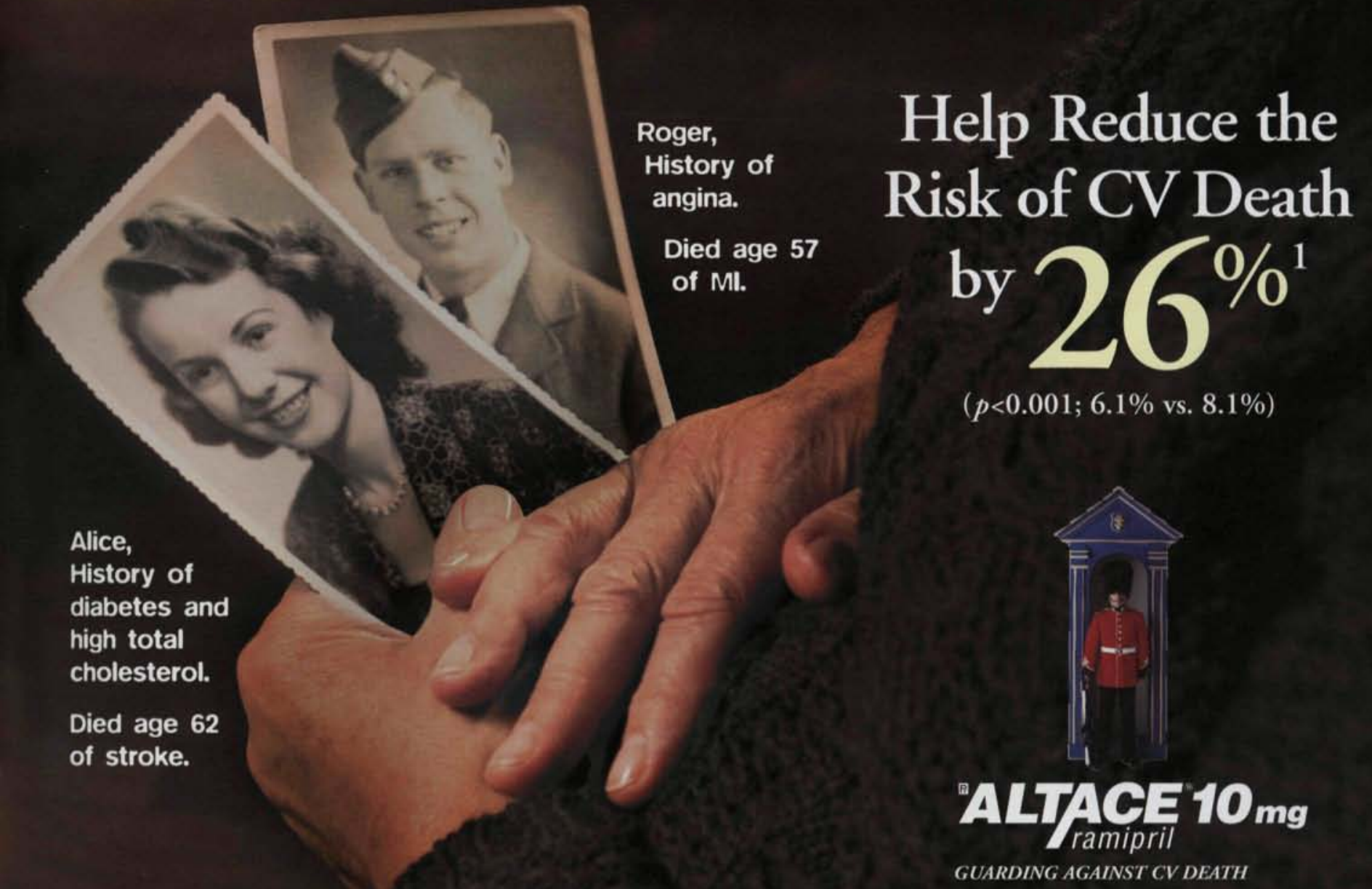

$(p<0.001 ; 6.1 \%$ vs. $8.1 \%)$

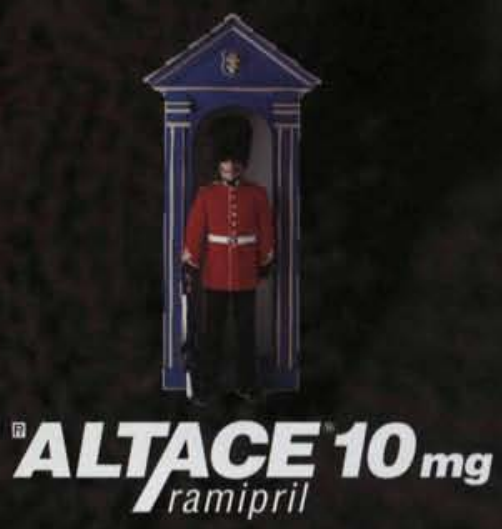

GUARDING AGAINST CV DEATH

ALTACE is indicated in the treatment of essential hypertension, normally when beta-blockers and diuretics are inappropriate. It may be used alone or in association with thiazide diuretics. ALTACE is indicated following acute myocardial infarction in clinically stable patients with signs of left ventricular dysfunction to improve survival and reduce hospitalizations for heart failure.

Results from the HOPE study showed that ALTACE improved survival in patients by reducing the risk of CV death by $26 \%(p<0.001 ; 6.1 \%$ vs. $8.1 \%)$. ALTACE may be used to reduce the risk of MI, stroke, or CV death in patients over age 55 who are at high risk of CV events because of a history of CAD, stroke, peripheral artery disease, or diabetes accompanied by at least 1 other CV risk factor such as hypertension, elevated total cholesterol levels, low HDL levels, cigarette smoking, or documented microalbuminuria.

Like other ACE inhibitors, ALTACE is not recommended for pregnant or lactating women and should be used with caution in patients with renal insufficiency. The most frequent adverse events occurring in clinical trials with ALTACE monotherapy in hypertensive patients who were treated for at least 1 year $(n=651)$ were: headache (15.1\%); dizziness (3.7\%); asthenia (3.7\%); chest pain (2.0\%); Discontinuation of therapy due to clinical adverse events was required in 5 patients $(0.8 \%)$.

The reasons for stopping treatment were cough (ramipril $7.3 \%$ vs. placebo $1.8 \%$ ); hypotension/dizziness (1.9\% vs. $1.5 \%)$ and edema ( $0.4 \%$ vs. $0.2 \%)$.

\section{ALTACE is the most prescribed ACEI among cardiologists:}

*IMS Health Canada: Canadian CompuScript Audit, Year 2002 Total Prescriptions 


\section{Dans le traitement au long cours de vos patients peuvent compter su

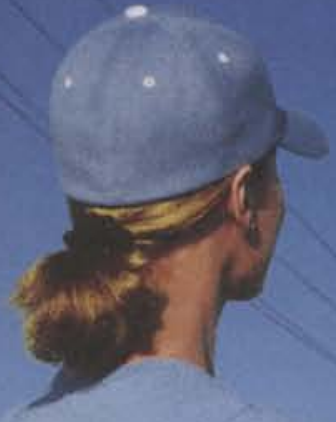

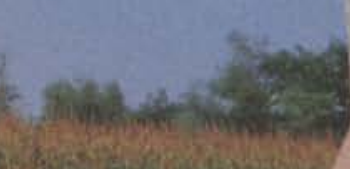
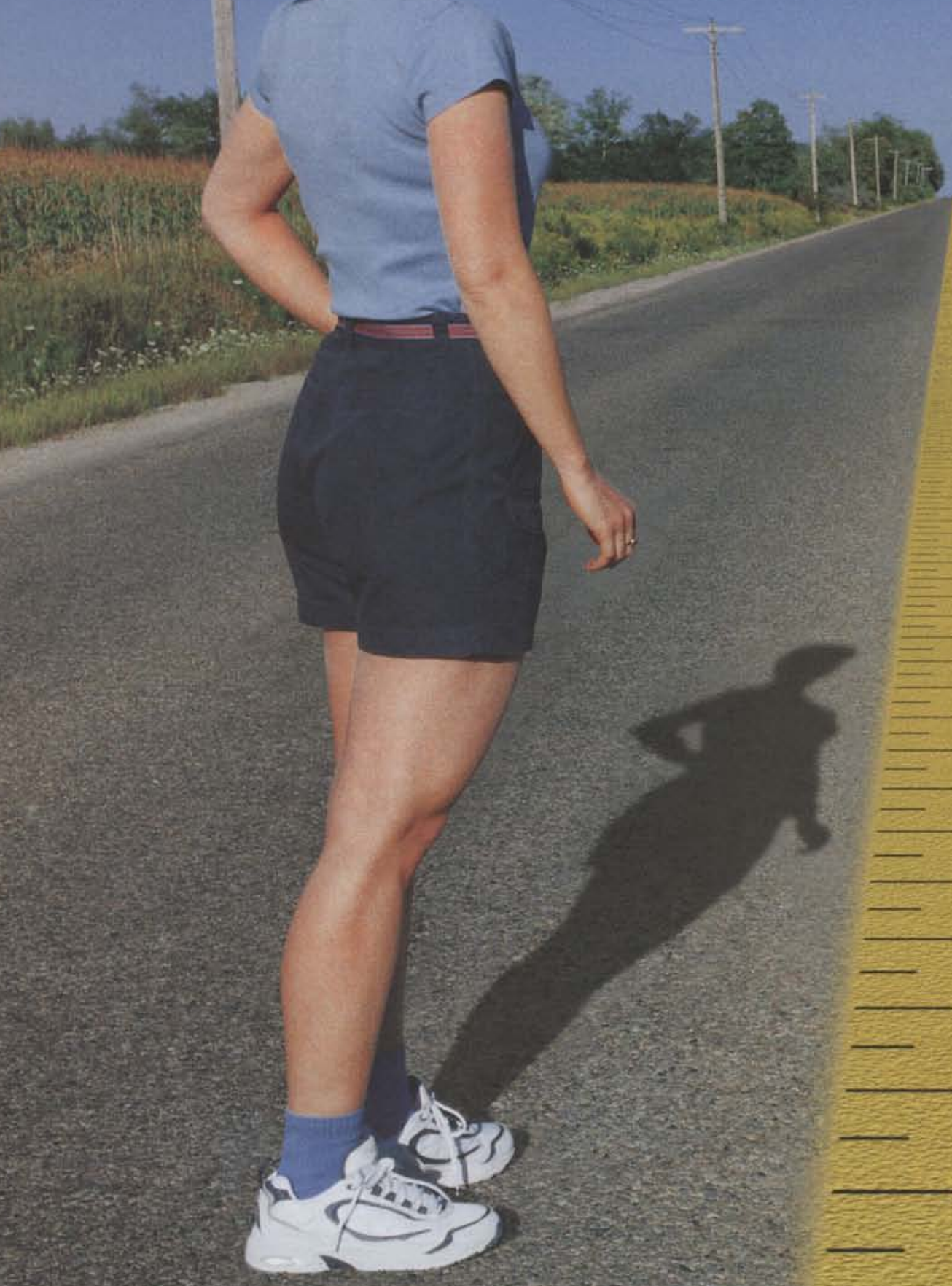


\section{SP rémittente, COPAXONE:}

\section{Effet démontré sur l'incapacité}

- Les patients traités par COPAXONE ont bénéficié d'une amélioration significative de la variation de la cote EDSS moyenne : $123 \%$ en faveur de l'effet thérapeutique $c$. le placebo sur deux ans $\left(-0,05\{n=125\}\right.$ c. $+0,21\{n=126, p=0,023)^{\prime}$.

\section{Réduction de la fréquence des poussées*}

- Réduction de $35 \%$ après neuf mois $(0,50\{n=113\}$ c. $0,77\{n=115\}$ placebo, moyenne, $p=0,0077)$.

- Réduction de $75 \%$ après deux ans $(0,60\{n=25\} \text { c. } 2,40\{n=25\} \text { placebo, moyenne, } p=0,005)^{\prime}$.

*Deux études indépendantes

\section{Profil d'innocuité établi}

- Innocuité démontrée depuis plus de sept ans dans les essais cliniques ${ }^{1}$.

- Aucune surveillance en laboratoire des anomalies hépatiques ou sanguines n'est recommandée'.

L'emploi de COPAXONE est indiqué chez les patients ambulatoires atteints de sclérose en plaques (SP) rémittente en vue de réduire la fréquence des poussées. L'innocuité et l'efficacité de COPAXONE* dans la sclérose en plaques chronique progressive n'ont pas été établies.

Au cours des essais comparatifs, les effets indésirables le plus fréquemment associés à I'utilisation de COPAXONE ${ }^{\circ}$ et dont l'incidence était supérieure à celle qui a été observée chez les sujets qui recevaient le placebo étaient les suivants : réactions au point d'injection $(2,4-66,4 \%$ c. $0-36,5 \%)$, vasodilatation $(27,2 \%$ c. $11,1 \%)$, douleur thoracique $(26,4 \%$ c. $10,3 \%)$, asthénie $(64,8 \%$ c. $61,9 \%)$, infection, douleur, nausées $(23,2 \%$ c. $17,5 \%)$, arthralgie $(24,8 \%$ c. $17,5 \%)$, anxiété et hypertonie $(35,2 \%$ c. $29,4 \%)$.

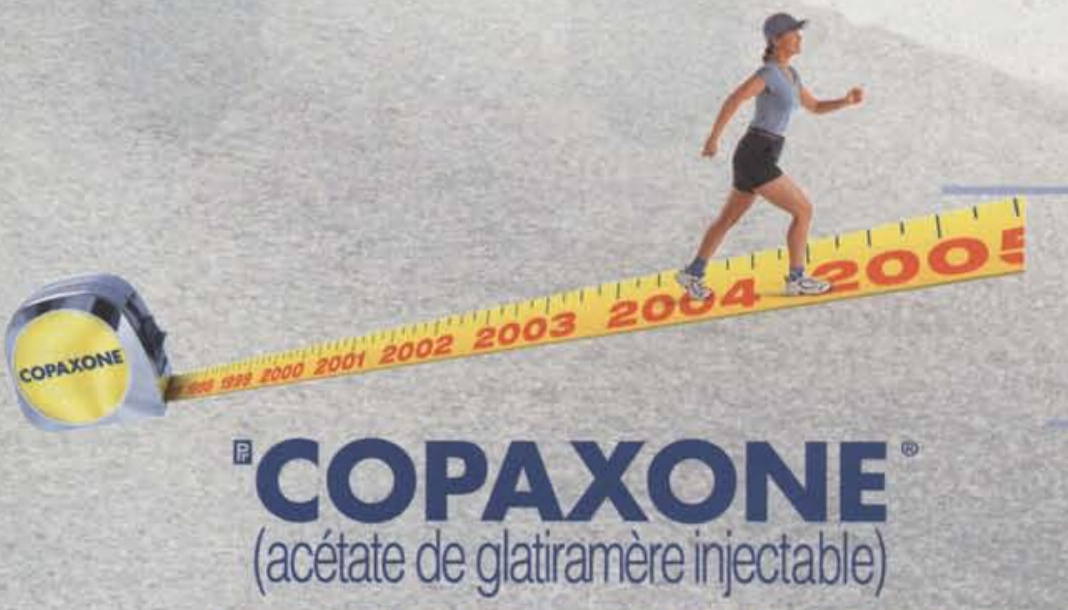

Traitement au long cours de la SP rémittente 


\section{If you think all IGIVs}

\section{are the same,}
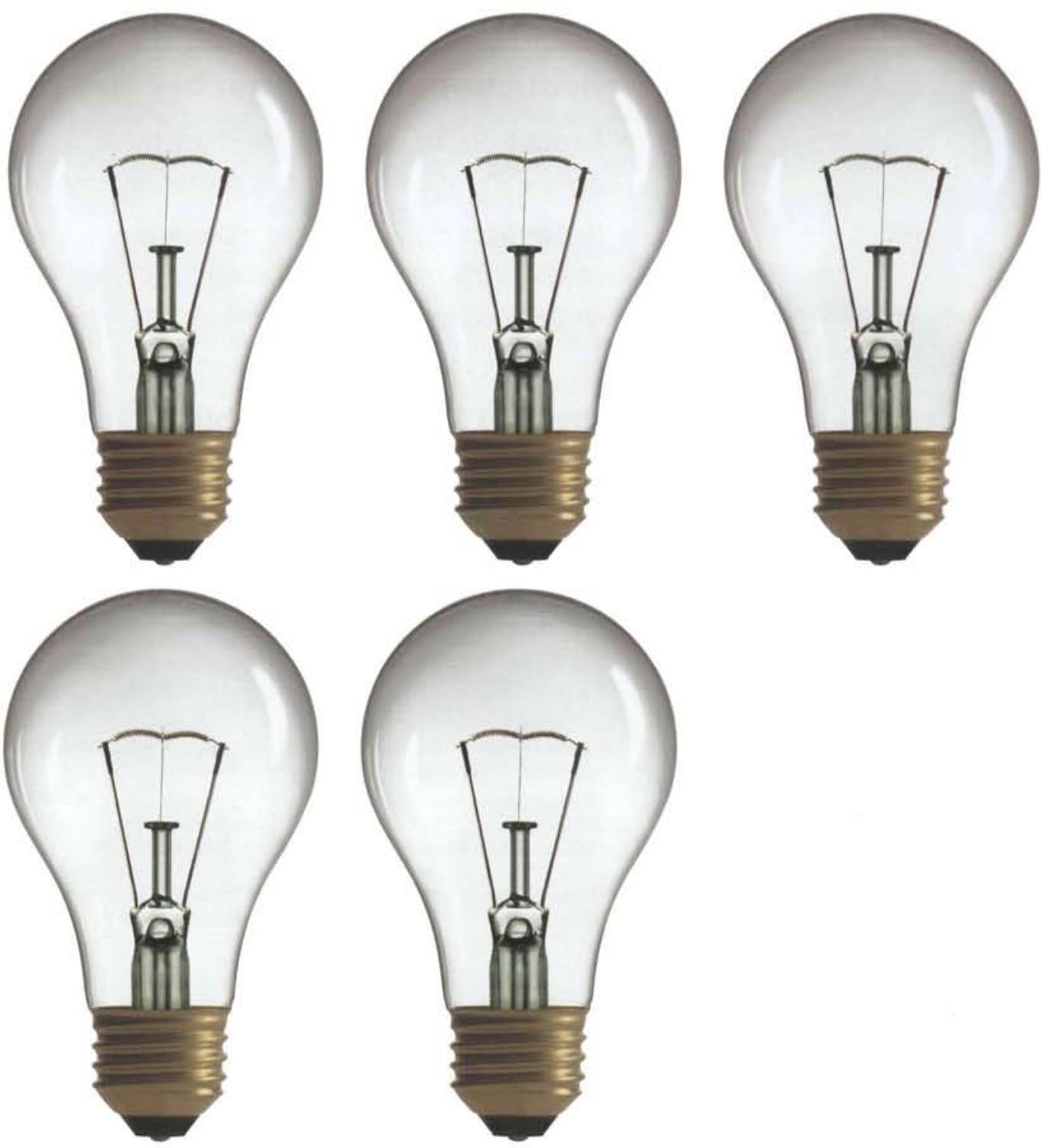

Gamunex ${ }^{T M}$ is contraindicated in individuals with known anaphylactic or severe systemic response to immune globulin (human). Individuals with severe, selective $\lg A$ deficiencies (serum $\lg A<0.05 \mathrm{~g} / \mathrm{L}$ ) who

Gamunex ${ }^{\mathrm{TM}}$ (Immune Globulin Intravenous [Human], 10\%, Caprylate/Chromatography Purified) is indicated: as replacement therapy of primary immune deficiency states in which severe impairment of antibody forming capacity has been shown; in idiopathic thrombocytopenic purpura (ITP) to rapidly raise platelet counts to prevent bleeding or to allow an ITP patient to undergo surgery; for the reduction of septicemia and other infections, interstitial pneumonia and acute graft vs host disease in first 100 days posttransplant in allogeneic bone marrow transplantation patients $\geq 20$ years of age; for the reduction of recurrent serious bacterial infections in those children with HIV who do not respond to or cannot tolerate antiretroviral combination therapy. have known antibody against $\lg A$ (anti-lgA antibody) should only receive Gamunex ${ }^{T M}$ with utmost cautionary measures.

Immune globulin intravenous (human) products have been associated with renal dysfunction, acute renal failure, osmotic nephrosis and death. Patients predisposed to acute renal failure should be administered the minimum concentration of human immune globulin products at the minimum rate of infusion.

Please see complete Prescribing Information on adjacent pages. 


\section{new Gamunex could change your mind.}

\section{The Gamunex ${ }^{T M}$ Difference.}

Innovative manufacturing process.

- Novel process designed to protect fragile lgG molecules.

- Utilizes new caprylate/chromatography process as an effective alternative to solvent-detergent for inactivating and removing enveloped viruses.

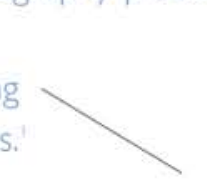

Excellent tolerability profile.

- In a study of 97 ITP patients, $90 \%$ of adverse events were mild-to-moderate and transient. **

Designed with convenience in mind.

- Liquid 10\% formulation reduces volume load vs $5 \%$ formulations."I

- High maximum infusion rate reduces infusion time.

- 5 months room temperature storage.

- Osmolality similar to physiologic osmolality.

- No added sugar stabilizers (such as sucrose or glucose).

- Most common adverse events reported in a study of 172 ITP patients: headache $(50 \%)$, vomiting $(13 \%)$, fever $(10 \%)$, nausea $(10 \%)$, rash $(6 \%)$, back pain $(6 \%)$.

† Initial infusion rate is 0.01 to $0.02 \mathrm{~mL} / \mathrm{kg}$ body weight/min for 30 minutes; if well tolerated, the rate may be gradually increased to a maximum of $0.14 \mathrm{~mL} / \mathrm{kg}$ body weight/min.

¥ May be stored at room temperature $\left(\leq 25^{\circ} \mathrm{C}\right)$ for 5 months during first 18 months of manufacture after which product must be used or discarded.

§Based on sizes of studies listed in Product Monographs of IGIV products currently marketed in Canada.

१Double-blind trial of 172 PID patients randomized to Gamunex ${ }^{\mathrm{TM}}$ or Gamimune ${ }^{\mathrm{s}} \mathrm{N}, 10 \%$.

"Double-blind trial of 97 ITP patients randomized to Gamunex" or Gamimune ${ }^{2} \mathrm{~N}, 10 \%$ response rate by day 7 .

HIITP study above; maintenance rate $\left(250 \times 10^{9}\right.$ for 7 days); $p=0.066$.

\#Comparative clinical significance unknown.

Most common adverse events reported in PID were: cough increased

$(1.7 \%)$, headache $(0.8 \%)$, fever $(0.1 \%)$ and pharyngitis $(0.8 \%)$.
New Gamunex ${ }^{\text {TM }}$ trials design.

- Largest pivotal trials in IGIV in patients with primary humoral immunodeficiency (PID) and idiopathic thrombocytopenic purpura (ITP). ${ }^{4}$

- Head-to-head comparison in more than 350 patients vs Gamimune N, 10\%.'

Proven efficacy in immune replacement therapy.

- Reduced the annual rate of validated sinopulmonary infection in PID (Gamunex ${ }^{\text {TM: }}$ 0.18 vs Gamimune ${ }^{\infty}$, 10\%: $0.43 . p=0.023)$.

Proven efficacy in

immunomodulatory therapy.

- Gamunex ${ }^{\top M}$ demonstrated excellent response rates in chronic ITP (100\%) and acute ITP $(90 \%)$. ${ }^{2 * *}$

- Excellent duration of platelet response (Gamunex ${ }^{14}$ : 74\% vs Gamimune N, 10\%:60\%).

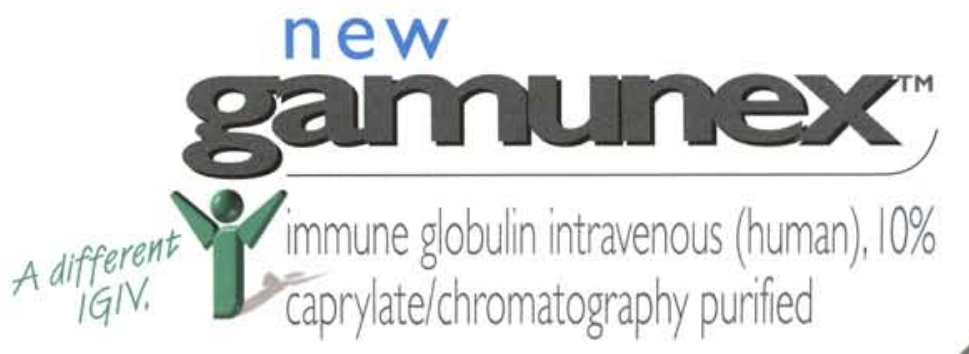




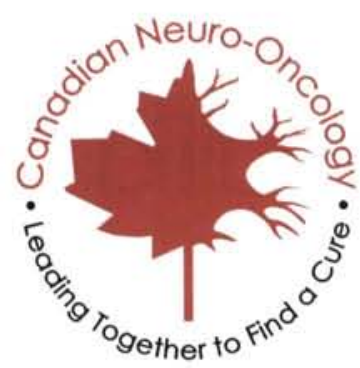

\section{$11^{\text {th }}$ Biennial Canadian Neuro-Oncology Meeting May 28-30, 2004 • Toronto • Ontario • Canada}

\section{CALL FOR ABSTRACTS}

\section{ABSTRACT DEADLINE: February 16, 2004}

The 2004 Canadian Neuro-Oncology Meeting will be held in Toronto, Ontario on May 28-30, 2004 and will take place at The Residence, 90 Gerrard Street West, Toronto.

The Scientific Committee of the $11^{\text {th }}$ Biennial Canadian Neuro-Oncology Meeting is now inviting abstracts for platform and poster presentation. Abstracts presented at the meeting will be published in the Canadian Journal of Neurological Sciences. The scientific program will encompass basic science, medical neuro-oncology, radiation neuro-oncology, pediatric neuro-oncology and quality of life/epidemiology.

\section{NEWLY ESTABLISHED YOUNG INVESTIGATOR RESEARCH AWARDS}

We are pleased to announce the establishment of three new "Young Investigator Awards" for which graduate students, postdoctoral fellows, residents in training and allied health professionals are eligible.

Two awards have been made possible by Schering Canada Inc. and the Canadian Brain Tumour Consortium:

- Canadian Brain Tumour Consortium Young Investigator Award in Basic Science

- Canadian Brain Tumour Consortium Young Investigator Award in Clinical Investigation plus

- The University Health Network Travel Award in Neuro-Oncology: To fund a young investigator to present their work at the World Federation of Neurosurgical Societies: Tumor Section Meeting, Jaipur, India, October 11-13, 2004.

\section{INSTRUCTIONS FOR SUBMISSION OF ABSTRACT}

1. Submit an electronic abstract (not exceeding 200 words) and use 12-point typeface in Word format only. Submit by February 16, 2004 to sandi.amaral@uhn.on.ca

2. The web does not support special characters and these must be spelled out in full (e.g., alpha, beta, greater than and equal to, etc.)

3. The abstract title must be in LOWER CASE LETTERS except for the first word and abbreviations, and followed by the authors' initials, family name(s), city and province(s). The presenting author MUST be asterisked.

Example: J. Smith, E. Clarke* (anywhere, Ontario), A. Brown (Elsewhere, Newfoundland).

4. Type the abstract body in a program on your own computer so that you can retain a copy for your records and submit the abstract in Word format.

5. Spell out special or unusual abbreviations in full words.

6. An individual may present more than one abstract. Abstracts submitted for presentation in poster or platform session will be reviewed by the Scientific Program Committee. Notification of acceptance and schedule information will be sent via email by April 1, 2004 .

\section{IMPORTANT DATES:}

\section{ABSTRACT DEADLINE: February 16, 2004 EARLY REGISTRATION DEADLINE: April 15, 2004}

Contact: Ms. Sandi Amaral, c/o $11^{\text {th }}$ Biennial Canadian Neuro-Oncology Meeting, Division of Neurosurgery,

Toronto Western Hospital, 399 Bathurst Street, West Wing 4-427, Toronto, Ontario, Canada M5T 2S8

T: (416) 603-5503 / F: (416) 603-5298 / Email: sandi.amaral@uhn.on.ca

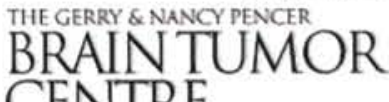

\begin{abstract}
The Arthur \& Sonia Labatt
Brain Tumour

Research Centre
\end{abstract}

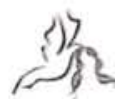

\section{The Crolla}

Family

Brain Tumour

Research Centre

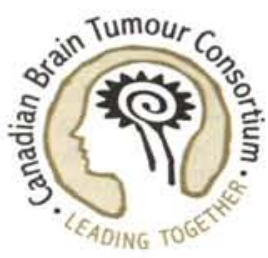




I N T R O D U C I N G A N N W

\section{From uncontrolled}

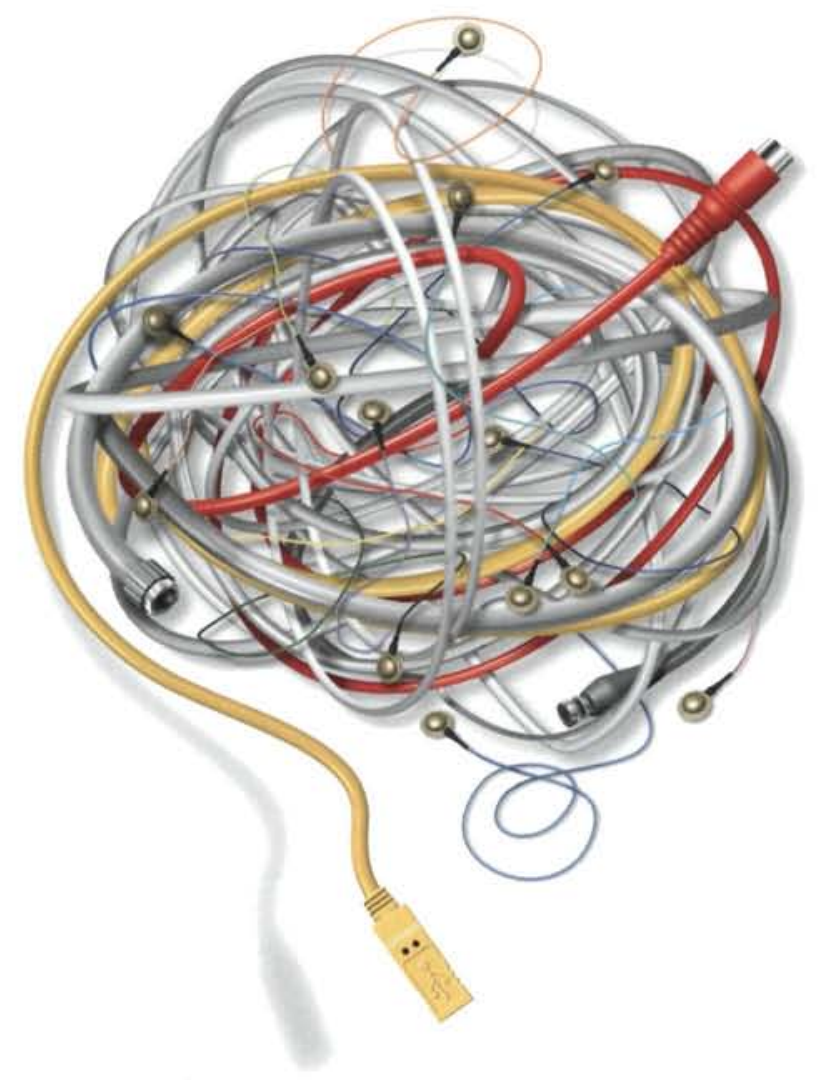

\section{New Keppra} connecting excellent profiles in efficacy and tolerability

\section{Effective control of seizures}

- Shown to provide up to 4 out of 10 refractory patients with $\geq 50 \%$ reduction in partial onset seizures $(p<0.001)$

- Rapid clinical improvement demonstrated by week 2 during a 14-week evaluation period $(p<0.001)^{1 *}$

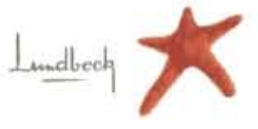
For more information, please refer to the complete Keppra Product Monograph,
Weppra is a registered trademark of UCB SA. Distributed by Lundbeck Canada Inc.
Keppra is indicated as adjunctive therapy in the management of patients with epilepsy who are not satisfactorily controlled by conventional therapy.

The most significant CNS adverse events were somnolence (Keppra $15 \%$ vs placebo $10 \%$ ) and asthenia (Keppra $14 \%$ vs placebo $10 \%$ ), behavioural/psychiatric symptoms (nonpsychotic: Keppra $14 \%$ vs placebo $6 \%$; psychotic: Keppra $1 \%$ vs placebo $0 \%$ ) and coordination difficulties (Keppra 3\% vs placebo $2 \%$ ). These adverse events were observed in controlled clinical trials with concomitant AEDs. 


\section{to control}

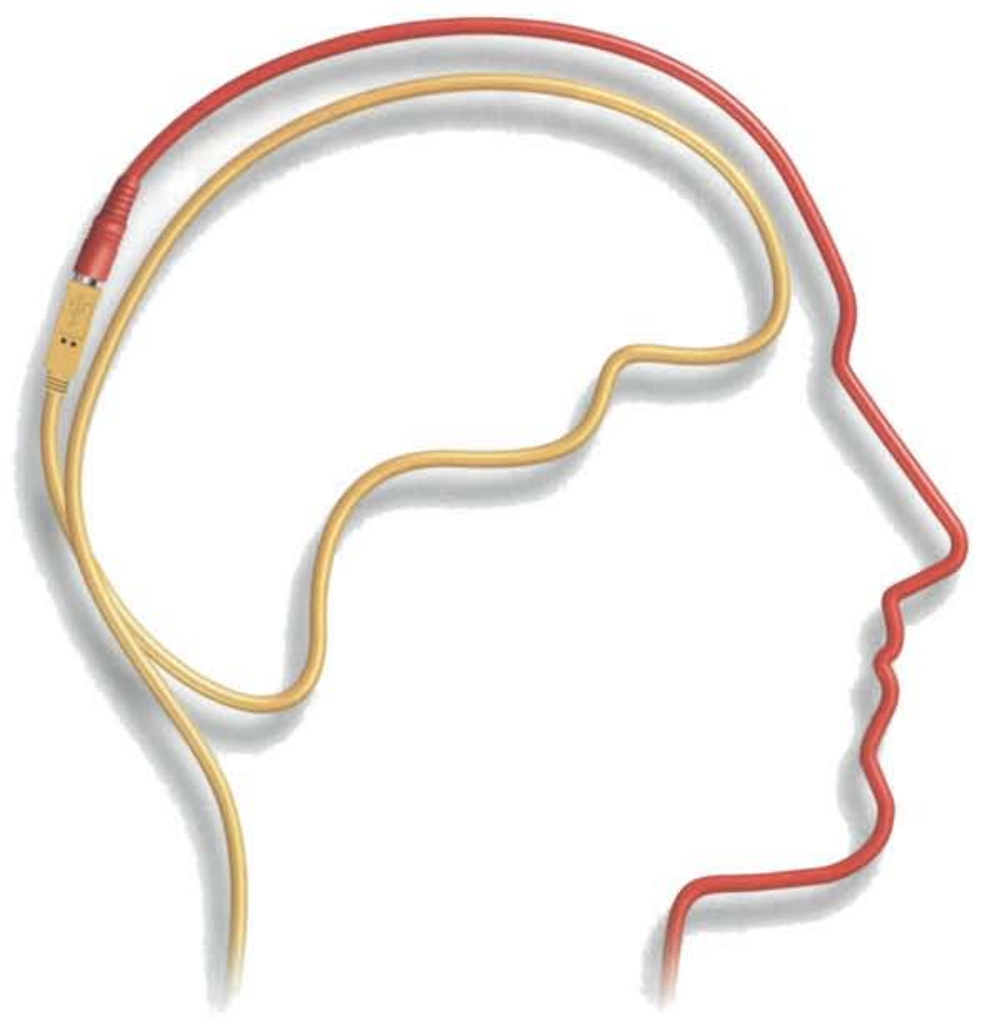

\section{Generally well tolerated}

- Favourable adverse event profile

- Adverse events not dose dependent ${ }^{2}$

- Low discontinuation or dosage reduction (Keppra $14.3 \%$ vs placebo $11.7 \%$ ) due to adverse events'
Efficacy and manageability right from the start

- Starting dose of $1000 \mathrm{mg} /$ day ( $500 \mathrm{mg}$ bid) shown to be effective and may be adjusted to a maximum of $3000 \mathrm{mg} /$ day if required

- No blood level monitoring required

no drug/drug interactions ${ }^{5}$ with other AEDs, warfarin, digoxin or between Keppra $500 \mathrm{mg}$ bid and a combination oral contraceptive $(0.03 \mathrm{mg}$ ethinyl estradiol and $0.15 \mathrm{mg}$ levonorgestrel) $)^{5}$
$\S$ Note: Pharmacokinetic interaction studies with contraceptives have not been conducted covering the full recommended dosage range of Keppra. Physicians should advise their female patients to be alert to any irregular vaginal bleeding or spotting and report any occurrences. Data from a 38-week multicentre, randomised, add-on, double-blind, placebo-controlled, parallelgroup trial. Study consisted of a 4-week titration period followed by a 14-week evaluation period. Patients received either levetiracetam $1000 \mathrm{mg} /$ day $(n=98), 3000 \mathrm{mg} /$ day $(n=101)$ or placebo $(n=95)$. Patient weekly seizure frequency was reduced over placebo, at week 2 of the evaluation period, by $24.9 \%(1.120 / 1.406)$ for Keppra $1000 \mathrm{mg} /$ day and 38.6\% (0.918/1.406) for Keppra $3000 \mathrm{mg} /$ day. The percentage of patients achieving $\geq 50 \%$ seizure reduction from baseline after the 18-week titration and evaluation period was $7.4 \%$ for placebo, $37.1 \%$ for Keppra $1000 \mathrm{mg} /$ day and $39.6 \%$ for Keppra $3000 \mathrm{mg} /$ day

$\uparrow$ Based on observations in clinical studies.

$\$ C_{\max }$ of levetiracetam's metabolite (ucb L057) was approximately doubled in presence of probenecid. Renal clearance of ucb 1057 decreased by $60 \%$ in presence of probenecid.

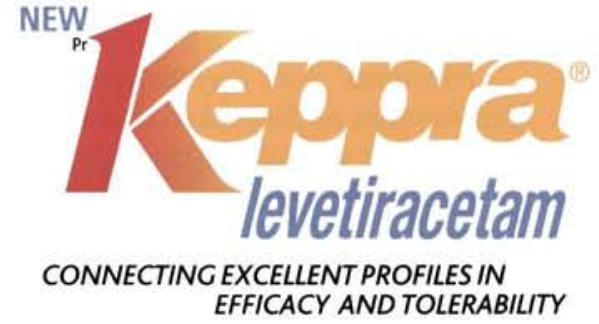




\title{
25 Years Ago in the Canadian Journal of Neurological Sciences
}

\author{
Seven Cases of Gilles de la Tourette's Syndrome: \\ Partial Relief with Clonazepam: A Pilot Study \\ M. Gonce and A. Barbeau
}

\begin{abstract}
Summary: The histories of seven consecutive case of Gilles de la Tourette's syndrome are presented to exemplify the range of clinical manifestations in this disease and to collate preliminary results with the new benzodiazepine, clonazepam, as a possible adjuvant therapy of this disorder. Controlled trials with clonazepam alone and in association with haloperidol are now justified. Five of our seven patients had a positive family history of tics, and two a confirmed family history of gout. Because clonazepam improves myoclonia and tics and because its mechanism of action possibly involves serotonin, we thought it worthwhile to study simultaneously the relative roles of serotonin and dopamine metabolism in the production of tics, and their relationship to possible defects in purine metabolism in Gilles de la Tourette's syndrome.
\end{abstract}

Can. J. Neurol. Sci. 1977:4:279

\section{Platelet Dopamine Uptake in Huntington's Chorea And GiLles DE LA TOURETTE's SyNDROME: EFFECT OF HALOPERIDOL}

\section{Roger F. Butterworth, Michel Gonce and André Barbeau}

Summary: Uptake of ${ }^{14} \mathrm{C}$-dopamine by human platelets has been studied in two diseases, namely Gilles de la Tourette's syndrome and Huntington's chorea, in which abnormal metabolism of dopamine has been implicated. Platelets from untreated Huntington's chorea patients showed a small increase in Km and Vmax.; platelets from patients in all other groups showed an uptake identical with the controls. Haloperidol $\left(10^{-5} \mathrm{M}\right)$ was also shown to be a strong non-competitive inhibitor of ${ }^{14} \mathrm{C}$-DA uptake by platelets. This property is probably unrelated to the drug's action in ameliorating the symptoms of Huntington's chorea which is likely related to the increase in cholinergic neuronal activity produced by neuroleptic blockade of dopamine receptors.

Can. J. Neurol. Sci. 1977;4:285

\section{Chroma-Memo-Flow Technique for Rapid Sequential Analysis of Regional CEREBral Blood Flow (RCBF) Responses Jørn Overgaard}

SUMMARY: This is the first report of a method of sequential regional cerebral blood flow ( $\mathrm{rCBF}$ ) analysis, called Croma-Memo-Flow. This technique is a computerized modification of the initial slope method of regional cerebral blood flow ( $\mathrm{rCBF}$ init.), allowing temporal resolution of the flow pattern by calculation of the slopes of sequential segments of the initial 1-2 minutes of the Xenon-133 washout curve. The same theoretical analysis applies to this method as to the rCBF init. method. Each flow calculation is based on the slope of a discrete 16 second segment of the initial washout; and each second the segment is advanced by one second. A new flow calculation is made each second and is displayed as a color coded map on a TV screen. Each map is labelled, indicating the time in seconds following Xenon injection, and sequential rCBF changes during the clearance period can be immediately visualized. This allows for almost instantaneous analysis and display of rapid or transient rCBF responses to activation and deactivation of the cerebral cortices.

The data is stored in a 35 channel memory for deliberate replay, photography, and analysis.

Functional tests may be applied during the initial washout period and both the magnitude and chronological relationships of the evoked regional cerebrovascular responses observed. A clinical study is presented to illustrate the possibilities of applying the technique to assess cortical reactivity.

Can. J. Neurol. Sci. 1978:5: 1 


\section{Unique proposed mode of action:}

Cholinesterase inhibition and nicotinic modulation ${ }^{12 .}$

\section{New REMINYL:}

The difference may be nicotinic modulation ${ }^{\prime}$

More than just cholinesterase inhibition, REMINYL enhances the action of acetylcholine through binding to an allosteric site on the nicotinic receptors ${ }^{1,2+}$

† Based on in vitro data. The clinical relevance to humans is unknown. The majority of common side effects occurred during the dose-escalation period and were primarily gastrointestinal. During maintenance therapy, the most common side effects were: REMINYL $16 \mathrm{mg} /$ day-nausea $(4 \%)$ and diarrhea (5\%); REMINYL 24 mg/day-nausea (6\%), vomiting $(6 \%)$ and anorexia $(5 \%)$.

REMINYL (galantamine hydrobromide) is indicated for the symptomatic treatment of patients with mild to moderate dementia of the Alzheimer's type. REMINYL has not been studied in controlled clinical trials for longer than 6 months. There is no evidence that galantamine alters the course of the underlying dementing process.

\section{References:}

1. REMINYL* (galantamine hydrobromide) Product Monograph, JANSSEN-ORTHO Inc.. October 29,2003.

2. Maelicke A, Albuquerque EX. Eur J Pharmacol 2000;393:165-170

t† Exception drug status

RMJA041001A QRQD WME

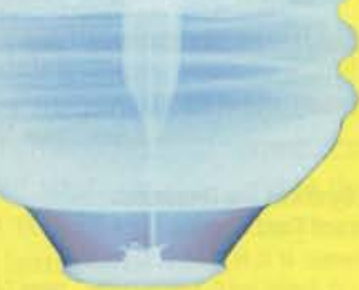

龵

19 Green Belt Drive,

Toronto, ON M3C 1 L9

www.janssen-ortho.com

2004 JANSSEN-ORTHO InC

- All trademark rights used under license 7955

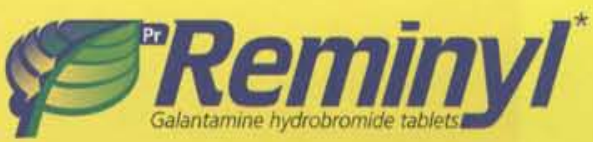

Think Cognition 


\section{Time to Celebrate 30 YeARS OF}

\section{Journal Publishing!}

\section{FIRST JOURNAL COVER, | 974}

THE CANADIAN JOURNAL OF NEUROLOGICAL SCIENCES

\section{LE JOURNAL CANADIEN DES SCIENCES NEUROLOGIQUES}

Editorial Frank B. Walsh page 5

Editor's Note R. T. Ross page 6

The Aphasia Quotient: The Taxonomic Approach to Measurement of Aphasic Disability Andrew Kertesz and Elizabeth Poole page 7

Complex Symptomatology Simulated by Unstructured Neural Nets

R. A. Cyrulnik, P.A. Anninos and R. Marsh page 17

CANADIAN ASSOCIATION OF ANATOMISTS SYMPOSIUM:

Functional Morphology of the Hypothalamus

Introduction D. G. Montemurro page 23

The Endocrine Hypothalamus: An Historical Review T. F. Lèvéque page 24

Localization of Neuroendocrine Functions within the Hypothalamus. Lee L. Bemardis page 29 Ultrastructure of Hypothalamic Neurons and of the Median Eminence. R. E. Clattenburg page 40

Scanning and Transmission Electron Microscopy of the Ependymal Lining of the Third Ventricle J. E. Bruni page 59

Role of the Ventricular System in Neuroendocrine Processes: Synthesis and Distribution of Thyrotropin Releasing Factor (TRF) in Hypothalamus and Third Ventricle K. M. Knigge, S. A. Joseph, D. Schock, A. J. Silverman, M. C. H. Ching, D. E. Scott, D. Zeman, and G. Krobish-Dudley page 74

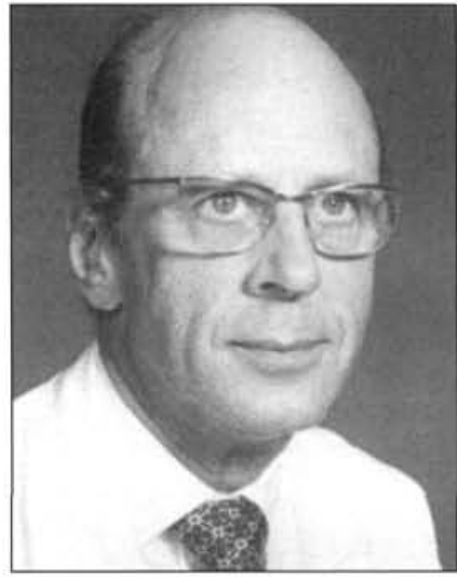

Dr. Robert T. Ross started the Canadian Journal of Neurological Sciences (CJNS) in Winnipeg, Manitoba in 1974. He was owner, editor, business and advertising manager, and distributor. In 1979, he sold it to the societies for one dollar.

Today, the Journal is published out of the Canadian Congress of Neurological Sciences (CCNS) Secretariat Office in Calgary, Alberta.

The Journal's editor and staff thank all of the past and present editors, authors, and reviewers, plus members of the Editorial Board and Publications Committee, for contributing to the Journal's success over the past 30 years. 